\title{
Discriminating between tectonism and climate signatures in palustrine deposits: Lessons from the Miocene of the Teruel Graben, NE Spain
}

\author{
Ana M. Alonso-Zarza a, b,*, Alfonso Meléndez ${ }^{\mathrm{c}}$, Rebeca Martín-García ${ }^{\mathrm{b}}$, \\ $\mathrm{M}^{\mathrm{a}}$ Josefa Herrero ${ }^{\mathrm{a}}$, Andrea Martín-Pérez ${ }^{\mathrm{a}}$ \\ Departamento de Petrología y Geoquímica, Fac., CC, Geologicas, Universidad Complutense de Madrid, C/José Antonio Novais, 28040, Madrid, Spain \\ b Instituto de Geociencias, UCM-CSIC, C/José Antonio Novais, 28040, Madrid, Spain \\ c Departamento de Ciencias de la Tierra, Universidad de Zaragoza, Zaragoza, 50009, Spain
}

Keywords:

Continental carbonates

Palustrine

Climate

Tectonism

Teruel Graben

Geochemistry

\begin{abstract}
A B S T R A C T
The Upper Miocene (Vallesian-Turolian) Unit II of the Teruel Graben comprises at its top a 25 m-thick sequence of palustrine deposits. Deposition of the entire unit commenced some 9 to $7 \mathrm{Ma}$ ago in a halfgraben basin. Here, via a recent quarry, we examine in detail the lateral and vertical distribution of Unit II's palustrine facies and their features to determine the palaeogeography and main controls on deposit formation. Our findings suggest the deposits formed at a low-gradient lake margin with different energy levels. These energy levels controlled the type of primary deposit within the lake; wackestone to packstone sediments formed in low-energy conditions, whereas cross-bedded rudstones to floatstones formed under higher energy conditions, by erosion and redeposition of prior lacustrine deposits. Pedogenic and diagenetic modifications of the primary sediments took place during sedimentary discontinuities (SD) when the lacustrine sediments were subaerially exposed. These processes serve to explain the formation of eight different palustrine limestones: limestones with root traces, mottled limestones, brecciated limestones, flat pebble breccias, granular limestones, micro-karstified limestones with laminar calcretes, carbonate mounds and clayey limestones with laminar calcretes. Based on the features and thicknesses of the modified sediments five different morphological stages ( $\mathrm{I}$ to $\mathrm{V}$ ) of palustrine carbonates are defined. Stage I is characterized by incipient mottling and brecciation. Stage II shows mottling and strong brecciation that lead to the formation of intraclast breccias, in which the fragments are mostly "in situ". In Stage III, the primary fabric is totally changed; intraclasts have moved and may have lost their initial morphology. This Stage III may also be characterized by the formation of micro-karst. Stage IV is typified by the presence of coated grains and thin root mats. The chronological data available suggest that the formation of Stage III (lacustrine deposition + palustrine modification) would require about $40,000 \mathrm{yr}$.

Facies and the SD record changes across short horizontal distances, and thus reflect the topography of prior sedimentation/modification events. Small $(50 \mathrm{~cm})$ highs with micro-karst have their SD counterparts in lower areas of the lake, in which the SD is indicated by desiccation and mottling. The topographic differences of the micro-karst were filled by intraclastic rudstones sourced by the adjacent carbonate flats. The example examined not only clearly sketches the morphology of ancient palustrine systems or wetlands, it also provides evidence that recycling of previous carbonate deposits played an important role as a sediment source, apart from biogenic or physical-chemical production processes.

Our geochemical data indicate LMC (Low Magnesian Calcite) as the main component and Fe contents lower than $1 \%$, except for the mottled areas that are richer in FeO. Stable isotope compositions provide $\delta^{18} \mathrm{O}$ values close to $-6.5 \%$ VPDB, and more varied ${ }^{13} \mathrm{C}(-3.39$ to $-6.97 \%$ PDB $)$. Oxygen and carbon values reveal no covariation and clear trends are lacking. The homogeneity of $\delta^{18} \mathrm{O}$ values reflects the intense effects of meteoric waters.

The deposition of these palustrine limestones took place under suitable semi-arid to sub-humid climates. Climate could also have a role in determining subaerial exposure periods. However, its imprint is not easy to detect neither in the geochemical signals nor in the vertical arrangement of the facies. This could be attributed to climate changes probably occurring over shorter periods than those that can be recorded in this type of sediment, such as the astronomical precession cycles, and suggests the unsuitability of palustrine carbonates for detailed palaeoclimate analyses.
\end{abstract}

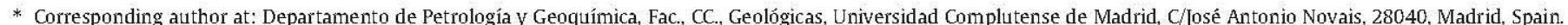
Tel.: + 3413944915 ; fax: + 3415442535

E-mail address: alonsoza@geo.ucm.es (A.M. Alonso-Zarza). 
Tectonism controlled the location of the main lacustrine depocentre close to the basin's main fault. The activity of this normal fault during the sedimentation of Unit II determined long-and short-term sedimentary sequences. Such sequences are the response to small-scale subsidence pulses followed by the infill of the created accommodation space by shallow lacustrine deposits, which underwent early pedogenic and diagenetic processes after subaerial exposure.

\section{Contents}

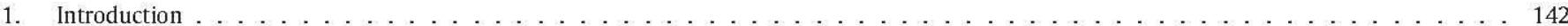

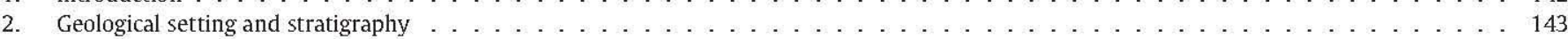

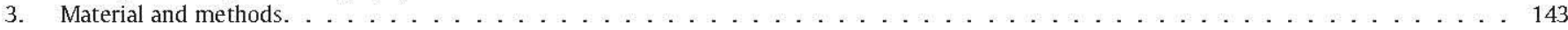

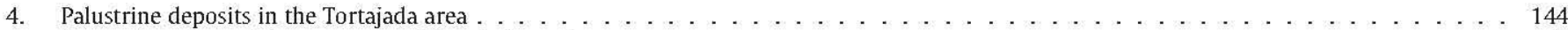

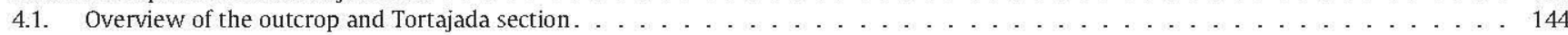

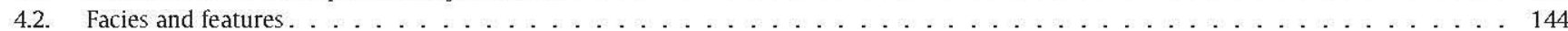

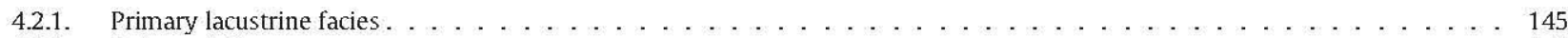

4.2.2. Pedogenic features . . . . . . . . . . . . . . . . . . . . . . . . . . . . . . . . . . . . . . . . . . . . .

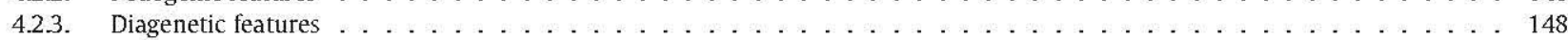

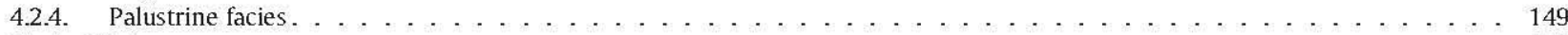

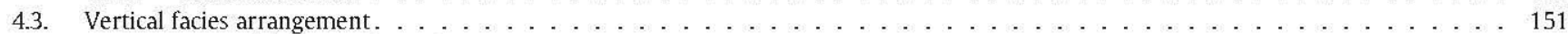

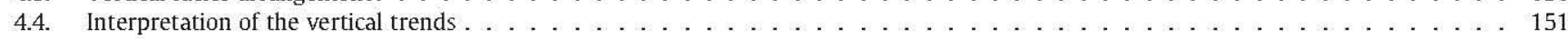

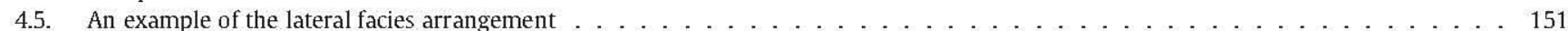

4.6. Interpretation of the lateral facies arrangement . . . . . . . . . . . . . . . . . . . . . . . . . . . . . . . . . . . .

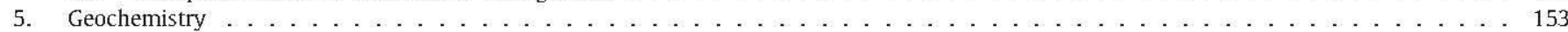

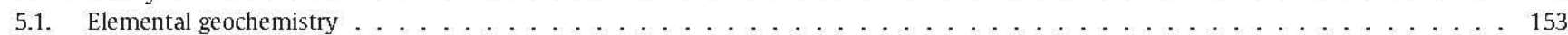

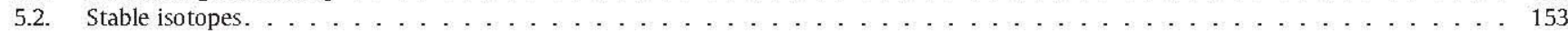

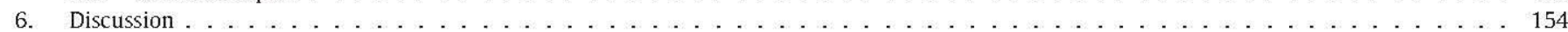

6.1. Record and significance of sedimentary discontinuities: morphological palustrine stages . . . . . . . . . . . . . . . . 154

6.2. Source, production and recycling of carbonate . . . . . . . . . . . . . . . . . . . . . . . . . . . . . . . . . .

6.3. Main controls on palustrine deposition: tectonism and climate . . . . . . . . . . . . . . . . . . . . . . 157

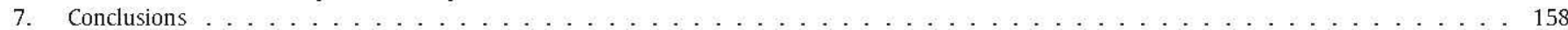

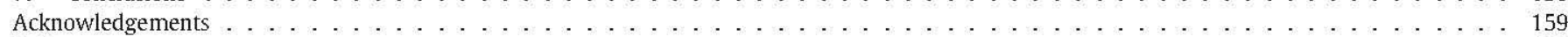

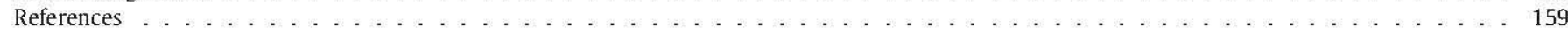

\section{Introduction}

Palustrine facies form part of a continuum of continental carbonate deposits, which include calcretes, tufas, travertines and lacustrine sediments. The specific environments are lacustrine-margin and wetland settings associated with carbonate-rich groundwaters and rivers. Ancient palustrine carbonate deposits and their modern analogues seasonal wetlands (Wright and Platt, 1995), are repositories of subtle environmental signals, such as climate data, but are also sensitive to tectonic effects and eustacy if they developed in coastal settings (MacNeil and Jones, 2006). In continental basins with no marine influence, climate and tectonism determine topography, hydrology, mechanisms of water supply and the source of calcium carbonate, either as ions or particles, within the lake (Alonso-Zarza and Wright, 2010).

Most palustrine carbonates arise from modification, through subaerial exposure processes, of carbonate-dominated muds deposited in lake environments. These physical (e.g. desiccation), chemical (e.g. hydromorphism, dissolution) and biological processes (e.g. bioturbation by soil organisms and plant activity) (Freytet and Plaziat, 1982) occur during pedogenesis and early meteoric diagenesis. The final product is complex since it is the result of several sedimentation events interrupted by a number of pedogenic + diagenetic events. The mineralogy, geochemistry, geometry, fossil content/traces and petrography of these deposits are the main data required to extract the palaeoenvironmental information contained in these carbonates, which may provide more detail than general climate or tectonism requirements. For example, detailed studies can reveal information on: (1) desiccation/exposure events, their lateral continuity and relative duration, (2) lake-margin morphology, (3) the relative time recorded in each sedimentation/pedogenic/diagenetic sequence, (4) the origin of the carbonate sediment, its source and deposition mechanisms, (5) the role of vegetation and other organisms, and (6) the processes involved in the formation of diagenetic products such as microspar and so-called "vadose silt". Collectively, these data serve to generate a dynamic model of palustrine environments that may complete previous ones (Platt and Wright, 1992; Freytet and Verrecchia, 2002; AlonsoZarza, 2003), and thus improve our current understanding of such complex systems and of their significance in basin analyses. In addition, the model could provide useful insight into the dynamics of recent and present seasonal wetlands and help design measures for their management (Ausseil et al., 2011).

This study was designed to address the dynamics of palustrine systems within a general context of active rift basins and semiarid climates. We discuss how these main factors control a number of processes (sediment and water supply, vegetation, sedimentation versus pedogenesis rate, diagenesis) that leave their imprint in the sediments providing valuable clues for interpreting ancient palaeoenvironments and their dynamics in space and time. All this is achieved through the analysis of an exceptional quarry outcrop within Unit II of the Miocene of the Teruel Graben (AlonsoZarza and Calvo, 2000). We conducted a field study including the analysis of both detailed vertical and lateral sections. Facies changes could be followed providing an outcrop-scale model of the dynamics of palustrine systems in which most primary, pedogenic and diagenetic features are preserved. According to the type and arrangement of facies we here: (1) define different morphological stages for these palustrine carbonates and (2) discuss the role of tectonics versus climate in the formation of long- and shortterm sedimentary sequences. 


\section{Geological setting and stratigraphy}

The Teruel Graben, or Teruel Fosse, occurs on the northeastern side of the Iberian Peninsula. The basin is oriented NNE-SSW and occupies an area approximately $100 \mathrm{~km}$ long by $15 \mathrm{~km}$ wide (Fig. 1). It is infilled by a rather complete Neogene succession up to $500 \mathrm{~m}$ in thickness (Moissenet, 1983, 1989). The basin is regarded as a halfgraben bounded by several NNE-SSW normal faults arranged "en echelon" in the eastern part of the basin (Anadón and Moissenet, 1996). Hanging-wall subsidence is westwards of the faults while footwall uplift is eastwards. This structure resulted in tilting of the Neogene deposits, which in general dip towards the ESE. The formation of the basin has been envisaged as related to extensional movements linked to rifting of the western Mediterranean in the Miocene (Anadón et al., 1989), and it is clear that evolution of the Teruel and the nearby Jiloca basin is consistent with the tectonic extensional regime of eastern Spain (Rubio and Simón, 2007). The main faults that bound the basin were active also during the Quaternary (Rubio and Simón, 2007; Lafuente et al., 2010). Another remarkable feature of the Teruel basin is the widespread occurrence of mammal sites, which have served to establish the chronostratigraphy of the basin's infill (Alcalá, 1994; van Dam, 1997; van Dam et al., 2001).

In the northern part of the Teruel Graben (Fig. 1), the Neogene succession is bounded by siliciclastic, carbonate and evaporitic formations of Triassic age along with Jurassic carbonate deposits. Palaeogene formations also occur in some parts of the basin's margins, especially to the north of the Teruel Graben. Neogene deposits in the central and western areas of the basin unconformably overlie Triassic, Jurassic and Palaeogene formations, but in the study area around Tortajada, at the eastern basin margin, the two lowest Miocene units are thrusted by the evaporitic Triassic Formations (Figs. 2 and 3). The oldest Neogene deposits have been dated as Lower Aragonian (van Dam, 1997). However, most of the basin's infill sequence that crops out in the region comprises sediments from the Lower Vallesian to Pliocene.

The Neogene sedimentary record of the basin's northern area includes five stratigraphic units (Alcalá et al., 2000; Anadón et al., 2004). The three lower units are Miocene in age, while the uppermost units are mostly ascribed to the Pliocene (Fig. 2). Unit I shows a maximum thickness of $50 \mathrm{~m}$ and consists of coarse red clastic facies in both the eastern and western basin margins; towards the central areas of the basin, these deposits grade into a sequence composed of fine clastic sediments at the base and lacustrine carbonates at the top. Unit II commences with red and green terrigenous deposits that sharply overlie the carbonates of the underlying unit. Units I and II show similar lateral and vertical facies arrangements but the carbonates of Unit II lie closer and are thicker as the eastern margin of the basin is approached. The sediments that form the top of Unit II are slightly folded, indicating active tectonism occurring prior to sedimentation of Unit III. In the study area, Unit III represents a drastic change in the sedimentary environments of the basin. This unit mostly comprises gypsum beds that towards the west and south grade laterally into red siliciclastic deposits and carbonates. Unit IV contains a variety of siliciclastic, carbonate, and gypsum facies and attains a thickness of $40 \mathrm{~m}$. Unit $V$ only crops out in the northern most part of the basin, and consists mainly of clastic deposits ending with calcretes. This unit indicates the development of a fluvial system flowing southwards (Sancho et al., 2002).

\section{Material and methods}

The characteristics of the outcrop are such that we were able to conduct a very detailed study of the basin's lacustrine deposits. First, we logged the overall vertical succession cut by the quarry and then we performed an in-depth study of the quarry's seven banks. In this study, the main vertical facies successions were determined. To record all the sedimentological information, selected parts of four banks were "in situ" traced by laying transparency films (about $3 \mathrm{~m}^{2}$ ) directly on the rock surface. Four 1:1 scale panels were obtained. Besides these panels, we prepared detail logs of some of the banks. For bank 3, including panel 3, eight logs separated one from the other by some $3 \mathrm{~m}$ were examined in detail, and at banks 5 and 7 three logs were examined. All these logs were used to construct our sedimentological model.

The mineralogy of the samples obtained was determined using a Philips XRD system operating at $40 \mathrm{kV}$ and $30 \mathrm{~mA}$ with a monochromated $\mathrm{CuK} \alpha$ radiation source. Stained thin sections were examined under a petrographic microscope. Scanning electron microscopy observations were performed using a JEOL 6.400 instrument working at $20 \mathrm{kV}$. Fractured surfaces were covered with gold, whereas

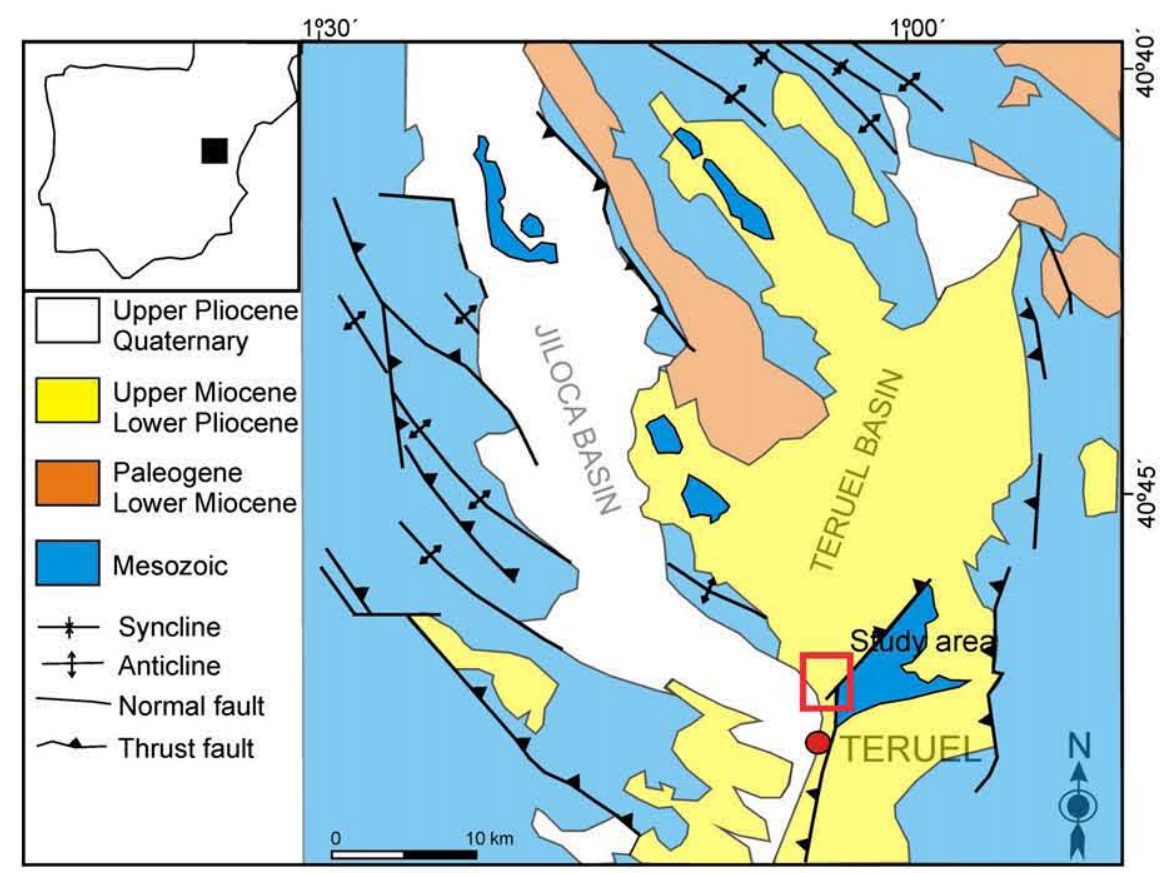

Fig. 1. Situation of the study area within the Teruel Graben, which is bounded my Mesozoic formations. Modified from Rubio and Simón (2007). 


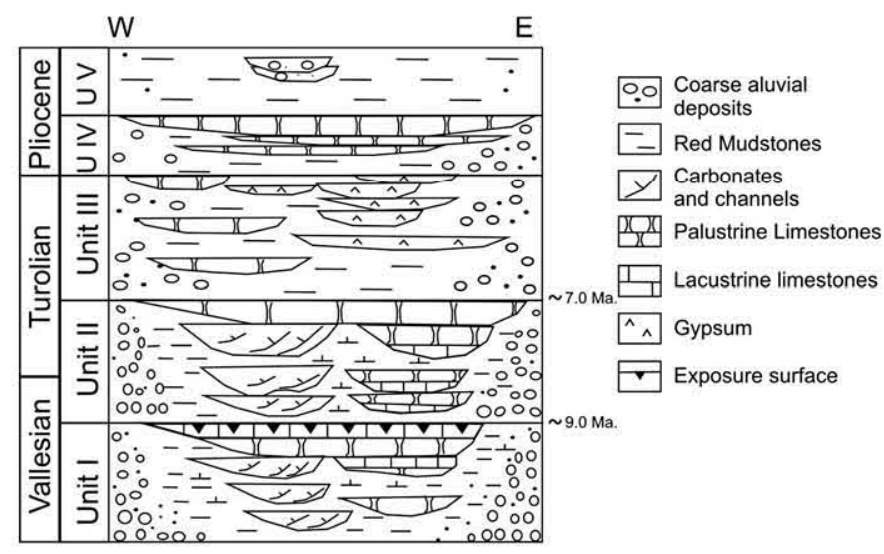

Fig. 2. Stratigraphy of the Neogene sedimentary record of the Teruel Graben. Modified from Alcalá et al. (2000).

polished ones were coated with carbon for backscattered electron imaging. For microprobe analyses, we used an electron probe microanalysis (EPMA) system equipped with wavelength dispersive spectrometers (WDS), model JXA 8.900 (JEOL) at the electron microscopy facility (CAI Luis Brú) of the Universidad Complutense de Madrid (Madrid, Spain). The standards used were those described by Jarosewich et al. (1980) and provided by the Smithsonian Institution, Washington.

After cleaning the quarry, samples for isotope analyses were drilled using a $4 \mathrm{~mm}$-diameter drill. To avoid contamination, the first fraction of powder obtained was discarded. Measurements were carried out at the Scientific Techniques facility of the Universidad Autónoma de Barcelona (Barcelona, Spain) on samples ground to $<100$ microns etched with $100 \%$ phosphoric acid at $70^{\circ} \mathrm{C}$. The reaction time for calcite is 3 minutes. For $\mathrm{CO}_{2}$ extraction, we used a Carbonate Kiel Device III coupled to a MAT-252 spectrometer supplied by Thermo Finningan, which automatically reproduces McCrea's (1950) method. The standard NBS-19 was used to validate the results.

\section{Palustrine deposits in the Tortajada area}

\subsection{Overview of the outcrop and Tortajada section}

Within the general distribution of the different lacustrine units of the Miocene and Pliocene of the Teruel Graben, carbonate lake deposits follow a main N-S trend (Alonso-Zarza and Calvo, 2000) and interfinger with red alluvial clastic deposits arising from the eastern and western margins of the basin. However, in the study site the limestones of Unit II are cut by the main eastern fault of the basin and no transitions to clastic deposits from the east are observed. Further to the south, the limestones discordantly onlap the basin's hinterland (Figs. 3 and 4). Towards the south and east, limestones interfinger with fine red clastic deposits.

The deposits examined constitute the carbonates of Unit II. In the study area, these carbonates attain a maximum thickness of $25 \mathrm{~m}$ (Fig. 5) close to the main fault. The carbonates are well stratified and beds are around $2 \mathrm{~m}$ thick. There are two intercalations of red clays containing carbonate nodules, and a topmost red clayey bed showing prism-shaped carbonate nodules and mottling. Collectively, these red clays are interpreted as Stage II to III calcretes according to the classification of Machette (1985).

\subsection{Facies and features}

Four different types of facies and/or features (primary, pedogenic, diagenetic and palustrine) were distinguished in the Tortajada quarry according to prior descriptions of palustrine deposits (Freytet and Verrecchia, 2002 or Alonso-Zarza and Wright, 2010). This discrimination is based on the original definition of a palustrine limestone by Freytet and Plaziat (1982): "a palustrine limestone must show the characteristics of the primary lacustrine deposit (organisms, sedimentary features) and characteristics due to later transformations (organisms, root traces, desiccation, pedogenic remobilizations)". According to this definition, we first describe the primary lacustrine facies and then examine pedogenic and diagenetic features at the scales of the outcrop and thin-section. These modification features

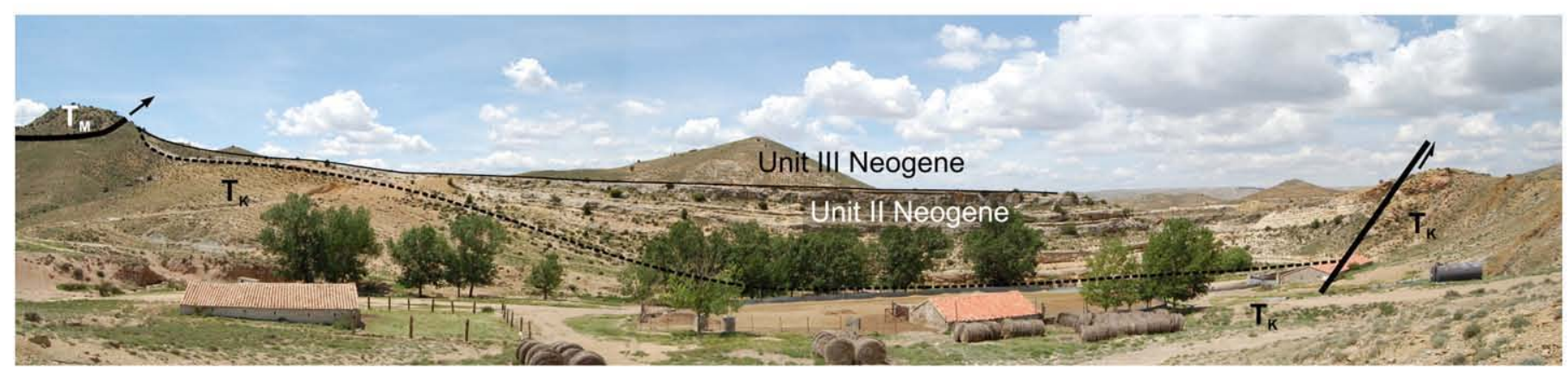

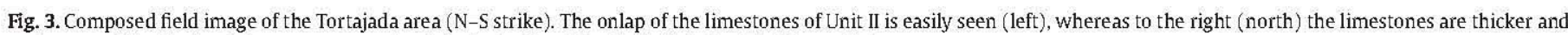
cut by one of the faults of the eastern margin of the basin. Tm: Muschelkalk facies; Tk: Keuper facies. 


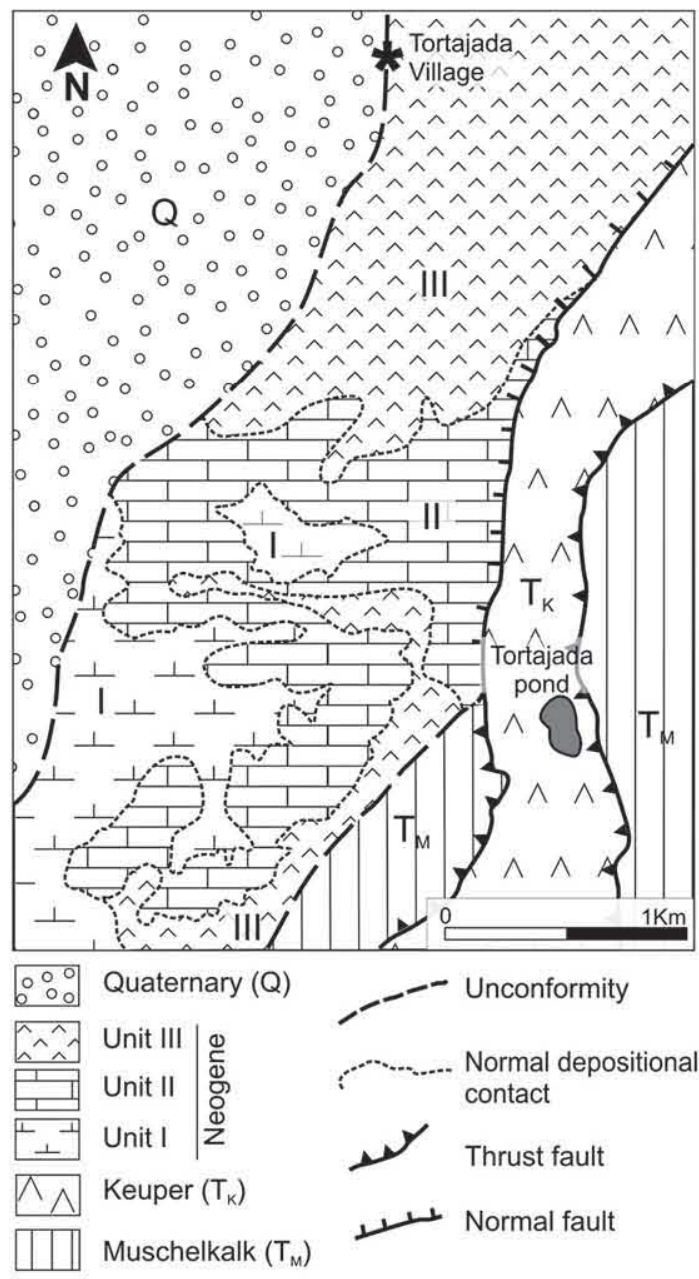

Fig. 4. Geological map of the studied area, showing the situation of the limestones of Unit II cut by one of the main faults that outline the eastern margin of the Graben.

occur widely throughout the palustrine facies described below. However, in some cases they are not easy to assign to a particular category, pedogenic or diagenetic, because the boundaries between these types of process are not always clear (Bustillo and Alonso-Zarza, 2007).

\subsubsection{Primary lacustrine facies}

Wackestone to packstones occur in tabular beds showing sharp, but sometimes very irregular, contacts with the underlying carbonates, their tops also being irregular and gradual in contacts with different palustrine facies (see description below). The mean preserved thickness of this facies is $0.7 \mathrm{~m}$. These wackestones to packstones (Fig. 6A) include oncoids, peloids, micritic intraclasts, charophyte stems and gyrogonites, ostracod shells, charophytes, and black pebbles. Oncoids, black clasts, and intraclasts are a few $\mathrm{mm}$ across on average. Siliciclastic quartz grains are also common. The beds are relatively homogeneous from base to top, and show a network of irregular horizontal planes along with other features described below. Less commonly, bioclast contents are very low and the limestone is a relatively homogeneous micrite (mudstone) with few quartz grains. In both situations, the mineralogy of the micrite is LMC.

Rudstones to floatstones with intraclasts, oncoids and black pebbles (Fig. 6B) commonly show cross-bedding, but are sometimes massive. They occur overlaying or filling the porosity of flat pebble breccias and micro-karst or on any other facies showing sharp bases. Clast/ grain size decreases upwards, while micrite content increases. This facies is composed of intraclasts $(0.2-15 \mathrm{~cm})$ of any of the limestone facies described previously and/or oncoids, and also contains quartz

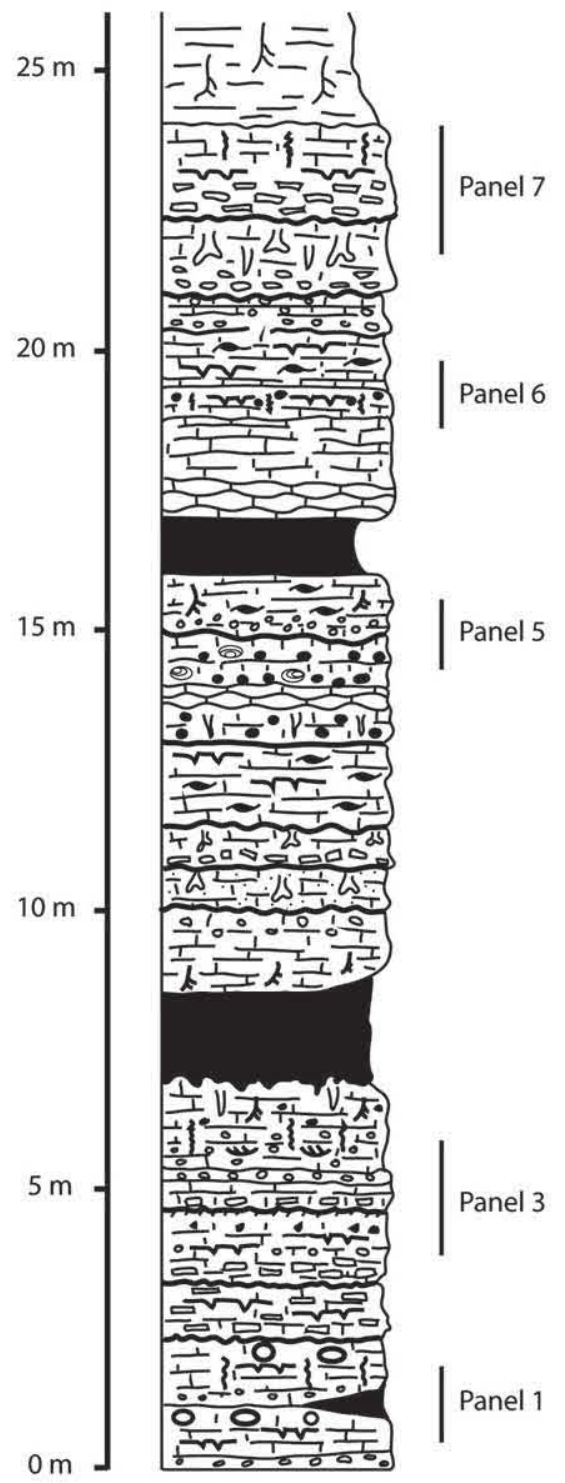

Red mudstone

잉구 Rudstone/Floatstone (gravel-size Wackestone/Packstone Rudstone/Floatstone (sand-size) Nodular/mottled limestone

\begin{tabular}{|c|c|c|c|}
\hline K & Roots & $\cdots$ & Black pebbles \\
\hline\{\} & Vertical cracks & $\sim$ & Fenestral structures \\
\hline m & Desiccation cracks & (Q) & Oncolites \\
\hline 000 & Flat pebble & 0 & Coated grains \\
\hline VV & Mottling & ש & Cross-bedding \\
\hline ¿s & Drab haloes & $\sim$ & Sedimentary discontinuity \\
\hline : & Intraclasts & ram & Karstified surface \\
\hline
\end{tabular}

Fig. 5. Sedimentological $\log$ of the carbonates of Unit II in the quarried area.

grains/clasts and black pebbles, all embedded in micrite. These limestones show diffuse mottling and commonly pass vertically and laterally to sandy biomicrites, mottled limestones or limestones containing root traces. The oncoids consist of a nucleus, which is commonly an intraclast, and an irregular white micritic coating (Fig. 6C). The size of the nucleus is much larger (up to $14 \mathrm{~cm}$ ) than the thickness of the coating (commonly less than $1 \mathrm{~cm}$ ).

The primary facies described here and those previously identified in the Teruel Graben are somewhat different from the commonly 

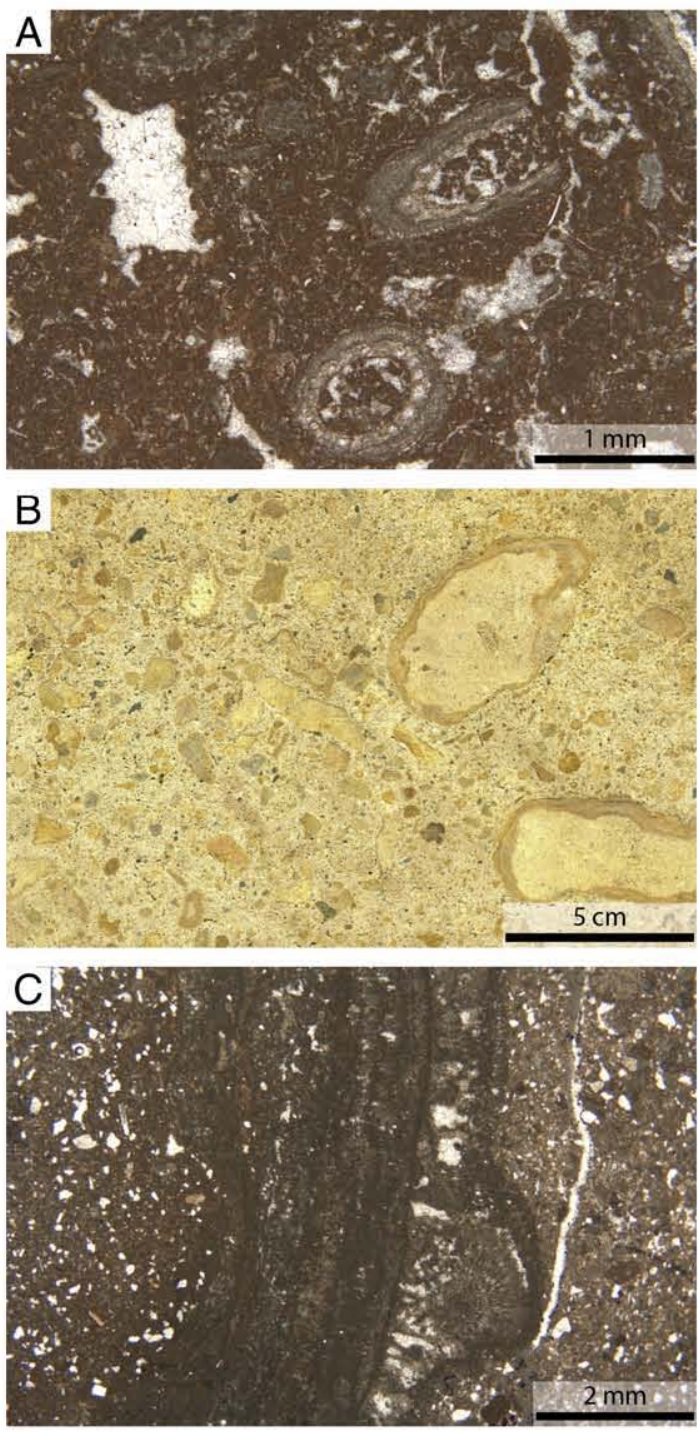

Fig. 6. Primary lacustrine sediment. A. Wackestones with calcified charophyte stems represent the low-energy deposits. B. Rudstones containing a large amount of intraclasts and some oncoids are an example of higher energy deposits within the lake. C. Detailed view of the coating of the oncoids.

described, more or less homogeneous, fine-grained micrite muds considered to be the primary deposits of palustrine systems (Freytet and Verrecchia, 2002; Alonso-Zarza and Wright, 2010). The two primary facies recognized here reflect several energy levels of the water body, from common quiet waters to higher energy channelized flows that carried the larger clasts and gave rise to cross-bedding. In addition, the frequent presence of micrite intraclasts points to reworking of early lithified mud carbonates by alluvial processes during lowstand. Thus, carbonate sedimentation in the lake, besides being the outcome of bio-chemical precipitation, was also produced by clastic intrabasinal carbonates. Most of the clasts were sourced from previous lacustrine limestones indicating the fragmentation, transportation and reworking of intrabasinal clasts. Their relatively coarse grain size and their infilling of pores in flat pebble breccias indicate these deposits constitute a new sedimentary phase/infill of the lake under higher energy conditions, as also shown by some of the sedimentary structures. Similar intraclastic limestones ranging from wackestones to rudstones are very common within the palustrine carbonates around the K-T boundary of SW France, where they formed as the result of brecciation, reworking and resedimentation of lithified lacustrine carbonates after emersion (Marty and Meyer, 2006).

\subsubsection{Pedogenic features}

Cracks several millimetres wide and decimetres long are typically horizontal, but vertical connections are common (Fig. 7A). Their morphology varies from very regular (flat) to irregular and sinuous or circumgranular. Some cracks remain totally open, but others are partially filled with reworked micritic grains, micrite, microspar, fibrous vadose cements and/or coarse spar calcite cement (see description below). This complex network of cracks could have been formed by mechanical processes of desiccation (Freytet, 1973). Despite no evidence found of desiccation of biological mats (Freytet and Verrecchia, 2002), roots notably contributed to either the initial formation of cracks and/or to their enlargement, as indicated by alveolar septal structures within the cracks.

Mottling is prominent both at the outcrop scale and under the microscope, and appears as diffuse, irregular orange to green haloes occurring in most facies of the Tortajada outcrop. Mottling is caused by iron remobilization induced by Eh changes due to a fluctuating water table (Freytet and Plaziat, 1982), although in the present case, manganese is also involved as indicated by the dark colour and the geochemistry. Similar mottling has also been detected in poorly drained palaeosols (PiPujol and Buurman, 1997).

Fine root cavities and fenestral structures. Fine roots are seen as pores several millimeters wide and a few centimeters long, with a preferred vertical orientation. Void structures are irregular and horizontal and sometimes enlarged by desiccation cracks. They are either empty of filled with microspar/coarse spar. Pores are irregular at the microscopic scale, occurring in most facies and widely distributed across most of the limestone beds.

Thin laminar calcretes and alveolar septal structures. Thin laminar calcretes (up to $1 \mathrm{~cm}$ thick) are topmost in some limestone (palustrine) beds or penetrate from the top to the base of the bed. Beige to red in colour, they are crudely laminated and in cases may cut or be cut by cracks. Beige calcretes are mostly composed of laminated micrite showing well developed alveolar septal structures (Fig. 7B) in which ovoidal pores (later filled) are lined with laminated micrite and equidimensional beige crystals, $10-40 \mu \mathrm{m}$ across (Fig. 7C). Alveolar septal structures are recognized in many of the facies described in this paper, not only in the laminar calcretes. Alveolar structures may trace the paths of prior cracks or, on the contrary, they may act as discontinuities for the development of larger cracks; these structures are generally interpreted as calcification related to fungal activity mostly in the vicinity of roots (Wright, 1986). The size and distribution of the beige crystals suggests they could be calcified root cells, similar to those described by Jaillard (1987) in calcareous soils. These calcified cells have been referred to as Microcodium (Wright et al., 1995; Kosir, 2004) and specifically Microcodium b (Esteban, 1972) or type 2 (Plaziat, 1984), and confirm the role of roots in the formation of alveolar septal structures.

Red laminar calcretes are the result of alternating grey microspar and micrite layers with red-staining due to the presence of iron oxides/hydroxides (Fig. 7D). Fibrous-radial calcitic spherulites, 30-120 $\mu \mathrm{m}$ in diameter, are the main components of these microsparitic layers. Although the origin of spherulites remains controversial, most authors agree that they are produced in association with mucilaginous bacteria or biofilms (Braissant et al., 2004; Chekroun et al., 2004; Parraga, et al., 2004). Whether or not they form in the presence of light is still not known, but the presence of spherulites corroding peloids and forming part of some pisolith coatings in Quatemary calcretes from the Ebro Basin, in Spain (Meléndez et al., 2011) suggests they could develop within the soil (Wright et al., 1996) and not at its surface. The formation of both types of laminar calcretes (beige and red) is clearly under biogenic control by plant roots and associated microorganisms. In effect, similar, although thicker, calcretes have been reported as rootcretes, calcified root mats or rhizogenic calcretes (Wright et al., 1988; Jones, 1992; Wright et al, 1995). When these calcretes occur at the top of bedrock soils, other organisms may be involved such as cyanobacteria, bacteria, fungi or lichens 

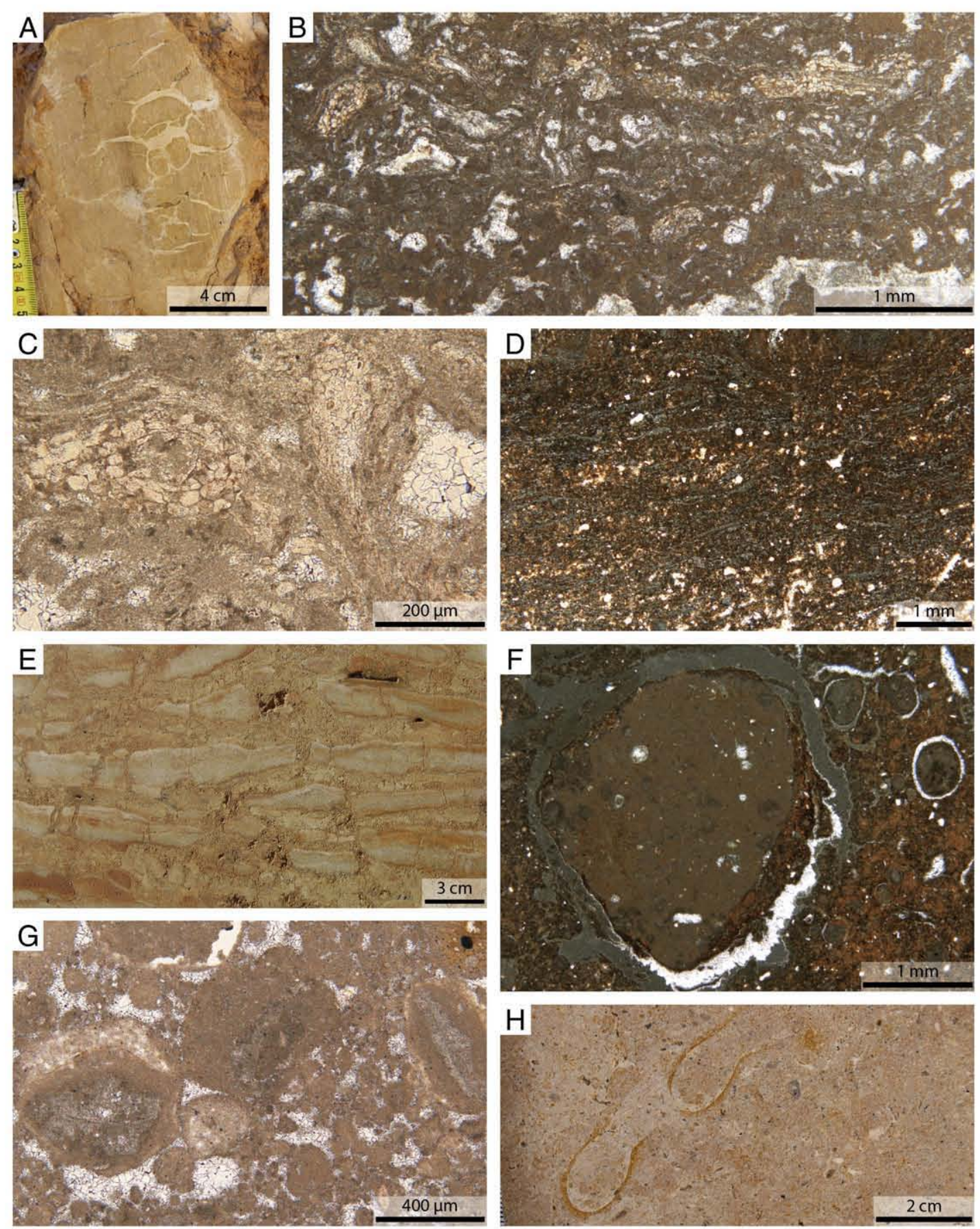

Fig. 7. Pedogenic features. A. Limestone showing different types of cracks, mostly circumgranular with infills varying from microspar to coarse spar. B. Alveolar septal structures showing well developed ovoidal pores and thin micritic laminations. C. Detailed view of B, showing calcified root cells. D. Thin red laminar calcrete consisting of irregular porous and micritic laminae. E. Large intraclasts showing micritic coatings formed either by alveolar septal structures or thin micritic red laminae. F. Coated grain showing asymmetrical red coatings. G. Rounded coated grains showing a thin coating and cemented by coarse spar. H. Cut of some of the trace fossils found in these limestones.

(Klappa, 1979; Vogt, 1984; Verrecchia and Verrecchia, 1994; Verrecchia et al., 1995). The presence of these thin calcretes or root mats indicates the total desiccation of the lake areas, where they occur, and incipient soil development.

Intraclasts are angular to subrounded grains/clasts $\mathrm{mm}$ to $\mathrm{cm}$ in size. They are flat to rectangular (Fig. 7E) and even spheroidal in shape. Composed of micrite or biomicrite with minor amounts of quartz, intraclasts appear white, yellow or orange, depending on the original limestones. The most striking feature is that some of these intraclasts are coated with white, yellow or orange mm-thick irregular laminae. Under the microscope, these laminae are similar to those described for the laminar calcretes, either red or containing alveolar septal structures. Within the red laminae, some spherulites similar to those of the laminar calcretes were observed. Intraclast formation is the result of brecciation of the micrite or biomicrite due to desiccation. The presence of both alveolar septal structures and spherulites indicates that root and microbes also contributed to the fragmentation of the original deposit.

Coated grains. In this section, we refer to the different types of coated grains distinguished in the Tortajada area, but excluding 
the oncoids described above. Two main types of coated grains exist:

Type 1 comprises subrounded grains $>1 \mathrm{~mm}$ across. Nuclei are varied and may be of different types: mottled, with alveolar structures, homogeneous and/or bioclastic micrite. The coatings are laminated, generally asymmetric, preferably with a developed underside. Coatings are composed of orange micrite, microspar, peloids and some quartz grains (Fig. 7F).

Type 2 comprises rounded grains 0.2 to $1 \mathrm{~mm}$ in diameter. These have a nucleus of micrite, which is mottled (orange) and has a grey thin irregular orange to grey coating and an external darker one (Fig. 7G). In some cases, these coated grains seem to be separated from the micrite groundmass by circumgranular desiccation cracks.

Coated grains are a typical feature of many lacustrine/palustrine deposits (Alonso-Zarza et al., 1992; Armenteros and Daley, 1998) as well as of calcretes (Calvet and Juliá, 1983). In palustrine settings, the formation of coated grains is considered to be the result of both inorganic and organic processes. Inorganic processes such as wetting and drying cycles are the main cause of desiccation and brecciation of lacustrine primary deposits and thus of the isolation of micrite fragments from the whole deposit to form isolated micritic fragments or nodules (Freytet and Plaziat, 1982; Armenteros and Daley, 1998). Roots and microorganisms can also contribute to the fragmentation of lacustrine deposits, as observed in the Miocene of the Madrid Basin (Alonso-Zarza et al., 1992). Similar fabrics have been described in peritidal settings and the process has been referred to as "grainification" (Mazzullo and Birdwell, 1989). The thicker coatings of type-1 coated grains show strong similarities with the coated grains found in calcretes. In these settings, coatings are the result of both inorganic (precipitation of micrite, microspar and vadose cements) or microbially induced carbonate precipitation within the soil, especially fungal filaments and cyanobacteria (Calvet and Juliá, 1983; Wright, 1990; Meléndez et al., 2011). Differences between type 1 and 2 reflect differences in time and/or intensity of desiccation processes as well as in biological activity, with type 1 indicating longer exposure periods required to form the coatings.

Peloids are fine $(0.1 \mathrm{~mm})$, micritic, rounded grains lacking a coating. They appear between any other coarse component and preferably nearby cracks or as their first infill. They also form part of some grain coatings. Peloids form through mechanical grain individualization but may also be the result of bioturbation by soil-inhabiting animals (Wright, 1983; Jones and Squair, 1989).

Insect Trace fossils are uncommon in these limestones, but some ovoidal structures around $2.5 \mathrm{~cm}$ long and $1 \mathrm{~cm}$ in diameter appear at the top of some limestone beds (Fig. $7 \mathrm{H}$ ). These structures have thin walls, about $1-2 \mathrm{~mm}$ thick and they are either empty of filled by sediment. This is the first time we have observed this feature in the Teruel Graben, the reason for this being that very good outcrop cuts are needed to find such structures in place, especially if the limestones are hard. We therefore think they could be more common than recognized at the moment. Although only tentatively speaking, these structures show similarities to those found in the Celliforma ichnofacies (Genise et al., 2010) that are characteristic of calcretes and palustrine carbonates (Alonso-Zarza et al., 2011).

\subsubsection{Diagenetic features}

Micro-karst occurs at the top of some limestone beds (Fig. 8A). It only affects as much as the top $50 \mathrm{~cm}$ of the bed in which it develops and its visible lateral extent is a few meters, hence the prefix micro. It appears as an irregular surface. Below the surface there is a network of irregular cavities of a few $\mathrm{cm}^{2}$. These cavities isolate irregular fragments of the host rock limestones (Fig. 8A). The cavities are filled by
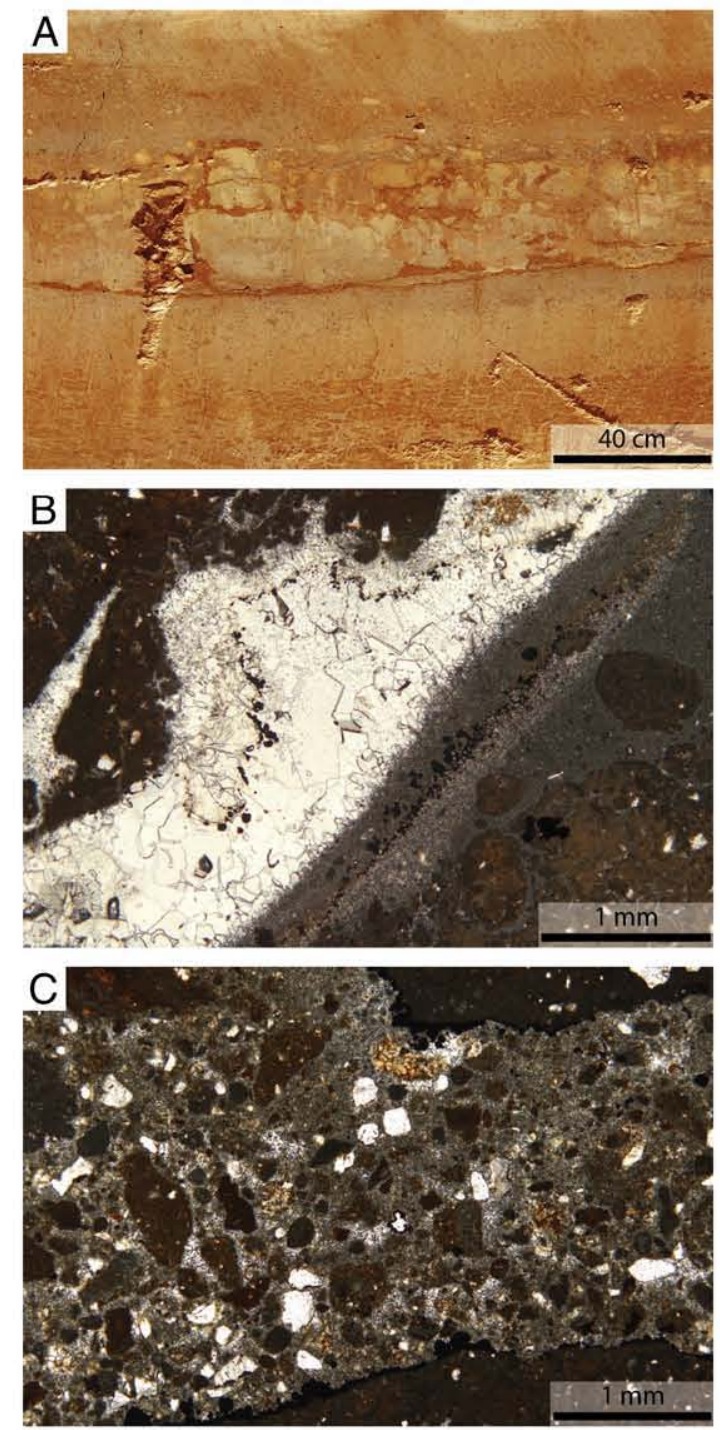

Fig. 8. Diagenetic features. A. View of the micro-karst recognized in panel 3. B. Crack filled by fine laminated microspar, containing spots richer in iron, and coarse calcite spar cement. C. Crack filled by coarse microspar including quartz grains, limestone fragments and coarse spar cement.

sandy to fine gravelly limestone and quartz clasts embedded within micrite, microspar and sparry calcite. Pseudo-microkarst has been considered among the most significant of palustrine features (Plaziat and Freytet, 1978) and consists of irregular, complex small cavities, which are mostly cylindrical and vertically elongated. The origin of these cavities is mostly attributed to roots and brecciation rather than dissolution, so the prefix "pseudo" is used. However, in our case study the effects of dissolution are clear, as shown by their irregular morphologies, the lack or any preferable vertical trend and the rounded margins of some cavities and fragments (Platt, 1989). We have thus avoided the use of "pseudo" and interpret this feature as a micro-karst that probably developed in small topographic highs of the system.

Microspar occurs in many of the deposits examined. It forms the infill of most fenestral, desiccation and root crack features. Often, it is not easy to define the boundary between micrite and microspar, as both may appear filling similar or even the same cavities. Micrite is smaller in size $(<4 \mu \mathrm{m})$ and appears as dark, relatively homogeneous masses. In contrast, microspar occurs as fine light grey or yellow (iron-stained) crystalline masses (Fig. 8B, C). Three main types of microspar can be identified. The first is a fine-crystalline microspar 
(3-6 $\mu \mathrm{m}$ ) and includes fine micritic filaments and peloids. The second type is laminated microspar, which contains peloids and iron/manganese oxides-hydroxides (Fig. 8B); their crystals are larger (6-15 $\mu \mathrm{m}$ ) and may show reverse grading. The third type is the coarser microspar $(8-15 \mu \mathrm{m})$ and includes relics of micrite and fragments of quartz and limestone (up to $2 \mathrm{~mm}$ ) as well as calcite crystals about $50 \mu \mathrm{m}$ across (Fig. 8C). The three types of microspar are composed of LMC. Microspar of similar characteristics has been commonly referred to as "vadose silt" (Dunham, 1969), but the processes involved in its formation are not clear. The different crystal sizes and the fact that only type 1 is really a fine microspar-micrite containing filaments and peloids suggest that part of the microspar may be an initial fine-crystalline micrite precipitate that subsequently underwent recrystallization as indicated by the relics ("ghosts") of micrite (third type). Lamination and the presence of some carbonate and siliciclastic grains support the idea of water moving through the cavities and filling them from base to top. The reverse grading of the second type points to a decreasing degree of saturation and/or decreasing of flow rate. In addition, oxides and hydroxides indicate the oxidizing conditions prevailing in these cavities.

Cements. The dominant cement is coarse calcite spar with the typical arrangement of the larger crystals ( $>60 \mu \mathrm{m}$ across) occupying the innermost pore areas, indicating dominant phreatic conditions during the spar's precipitation. Some prismatic cements (about $30 \mu \mathrm{m}$ ) hang on coated grains or appear intercalated between the microspar infills of cavities formed under vadose conditions.

$\mathrm{Fe} / \mathrm{Mn}$ oxides/hydroxides, widely distributed in the limestones examined, are responsible for their yellow to orange colour and appear: (1) staining and constituting part of the coatings on some grains, (2) outlining cracks and cavities as the first cement, (3) staining micrite and microspar (Fig. 8B), and (4) as spheroids (0.1 mm) intercalated within the laminated microspar and within coarse calcite spar. Iron and also manganese remobilization was controlled by oscillation of the water table (Freytet, 1973) and specifically in our study case through wetting and desiccation processes. The fact that some of the iron and manganese occur in cavities points to the remobilization of oxides/hydroxides also during early diagenesis due to Eh changes in vadose and phreatic environments.

\subsubsection{Palustrine facies}

In this section, we define the main palustrine facies of the study area. Each facies is the result of modification of the primary facies by pedogenic or diagenetic features and/or processes. Because of the continuum of palustrine facies, similarities exist among some of their features.

(1) Limestones with root traces and fenestral structures occur as beds about $0.5-1 \mathrm{~m}$ thick (Fig. 9A). These limestones are micrites to biomicrites harbouring oncoids and scarce charophyte, ostracod and mollusc fragments. Although light in colour, the limestones can show some mottling. Of all the main facies, these show the fewest pedogenic and diagenetic alterations, and so preserve most primary structures and textures.

(2) Mottled limestones are yellow to orange (Fig. 9B). Bed thickness can reach $1.5 \mathrm{~m}$. They are micrites or biomicrites that show fine root traces such as the pores earlier described. Very rarely, some ovoidal trace fossils can be distinguished especially at the bed tops. These limestones show a fine $(\mathrm{mm})$ network of desiccation cracks filled with micrite/microspar and coarse spar. As indicated above, these facies reflect changes in the water table and drying of the water body.

(3) Brecciated limestones do not form individual beds but occur as a modification of the top of the underlying facies, which is cut by a horizontal and, less prominent, vertical network of cracks. The lower boundary between the underlying facies and the brecciated limestones is very gradual. The tops of the bed are wavy. Here we include limestones in which relatively large fragments (decimetric) are separated by the crack network (Fig. 9C, D). Cracks show a very complex infill including micrite, the three types of microspar, and fibrous and blocky spar cements. In palustrine environments, "in situ" brecciation processes are caused by desiccation of the muds and/or biomicrites (Freytet, 1973). In addition, in the limestones studied, the frequent presence of alveolar structures at the margins of desiccated fragments also suggests a role for plants in fragmenting the early lithified sediment.

(4) Flat pebble breccias are probably the most characteristic features of the quarry. They occur on the top of brecciated limestones and the main difference is that this facies contains isolated limestone fragments (intraclasts) some $4-10 \mathrm{~cm}$ long and $2-5 \mathrm{~cm}$ wide (Fig. 9C, D). All intraclasts (see description above, Section 4.2.2) share the same composition and texture, since they come from the same underlying deposits. The fragments may be distributed parallel to the bedding, but often they show an anticline-like distribution (Fig. 9E). These anticlines are about $0.5 \mathrm{~m}$ high and $1-2 \mathrm{~m}$ wide. The space between the intraclasts is filled with sand-size intraclasts, coated grains and oncoids, as well as siliciclastic grains. All these grains are embedded in a micrite/microspar matrix. The formation of intraclastic breccias or intramicrites, in which clasts are easily identified as arising from the underlying beds (Wells, 1983), indicate more intense brecciation processes and slight movements of the fragments on the exposure surface or on the floor of the newer lake body. The size and morphology of clasts (and/or breccia fragments) seem to depend on the extent of lithification before erosion and the amount of reworking prior to (Wells, 1983) and during deposition. The anticline-like distribution of intraclasts is in part inherited from the wavy tops of underlying brecciated limestones and correlates with an irregular morphology produced by desiccation-wetting processes and/or by the small microrelief caused by the presence of plants that disturbed the sediment.

(5) Granular limestones are not easy to separate into individual beds as they constitute parts of beds containing other facies. They are yellow to orange and consist of more or less rounded micritic coated grains (types 1 and 2) (Fig. 9F). Peloids are also very common in this facies. Both peloids and coated grains occur within a micrite matrix cut by cracks and alveolar septal structures. Two main types of crack are recognized. The first includes circumgranular cracks that fragment the micrite groundmass and contribute to the individualization of the grains. These cracks are filled with microspar and coarse spar. The second type consists of enlarged horizontal and vertical cracks that form a complex network and contribute to the formation of enlarged cavities. These enlarged cavities, sometimes bounded by alveolar septal structures, are filled with microspar and limestone and bioclast fragments, quartz grains and $\mathrm{Mn}$ oxides, and fibrous and blocky spar with some oxides and micrite intercalations.

The above are the more complex palustrine facies (Armenteros et al., 1997; Huerta and Armenteros, 2005). Their formation is the combined effect of mechanical fragmentation either by desiccation or by root penetration of the primary deposits leading to gradual separation or individualization of carbonate grains (grainification) and then to their coating (Alonso-Zarza et al., 1992; Armenteros and Daley, 1998). Later reworking, organic activity, internal sedimentation, and vadose and phreatic cementation produced a complex limestone fabric (AlonsoZarza et al., 1992) of a compound ooidal microstructure (Armenteros and Daley, 1998) or syngenetic grainstone (Mazzullo and Birdwell, 1989), which reflects the most intense alteration of the initial deposit. However, these modifications 

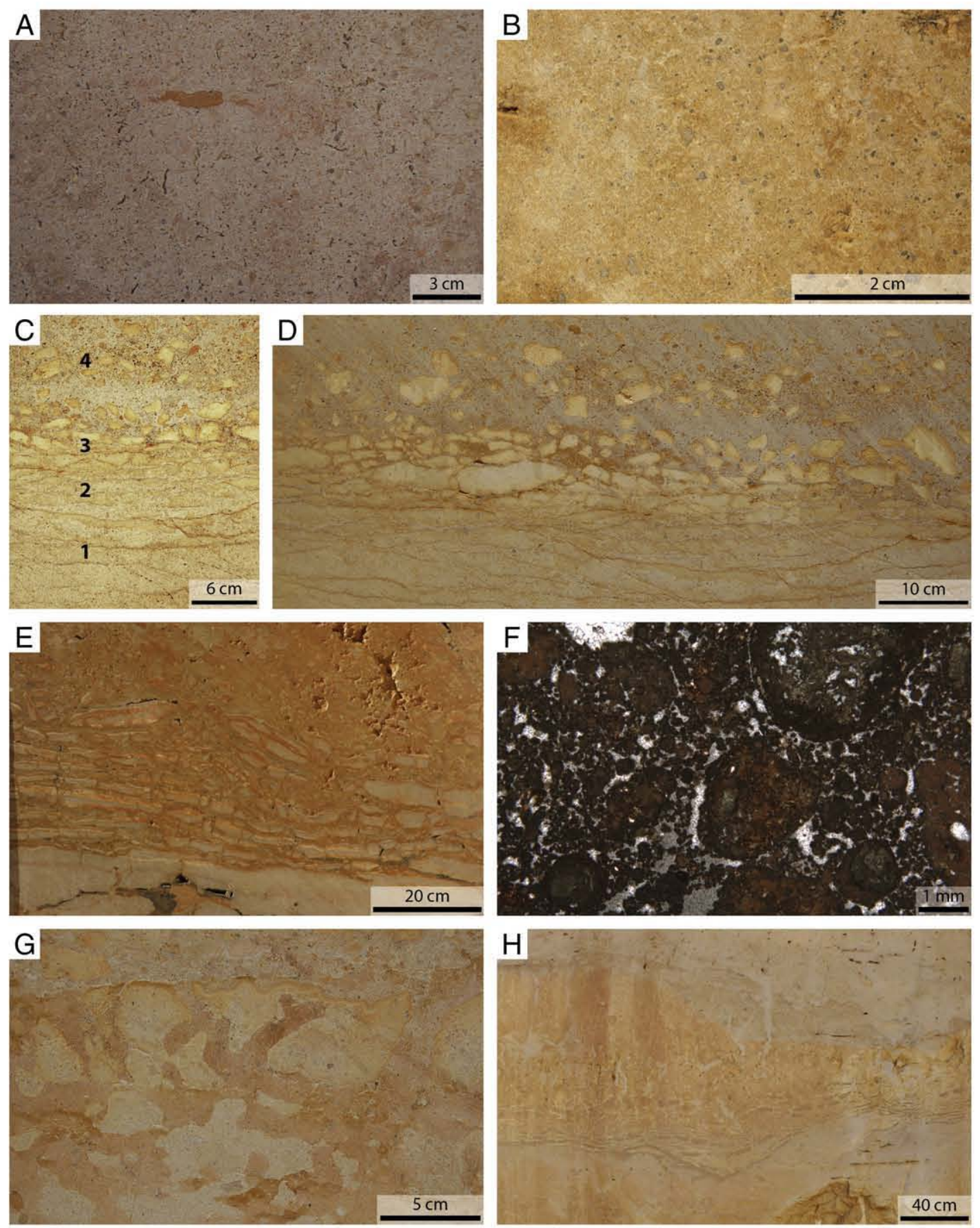

Fig. 9. A. Limestones with fine root pores, mottling and fenestral structure. B. Mottled limestones also show some sand-size limestone intraclasts. C. Desiccated limestones (1) grading to brecciated limestones (2) and to (3) flat pebble breccias. The top most (4) correspond to the intraclastic rudstones. D. Detailed view of flat pebble breccias. E. Flat pebbles showing and anticline-like arrangement grading to clayly limestones containing coated grains and thin root mats. F. Microphotograph of granular limestones, some of the grains show thin coatings. G. Detailed view of the sandy limestones with micro-karst and thin laminar calcretes. H. Carbonate mound from panel 4 , the base is irregular and composed by flat pebble breccias.

occurred soon after sedimentation (Alonso-Zarza et al., 2011) and the resulting limestone may constitute the substrate for the next pedogenic or lacustrine cycle.

(6) Sandy limestones with micro-karst and laminar calcretes are not too laterally continuous. This facies passes laterally to desiccated, granular or intraclastic limestones. The limestones are wackestones to packstones and contain intraclasts, oncoids, bioclasts and sand-size (siliciclastic and carbonate) grains. The most outstanding feature is that the micro-karst surface (see description above)(Fig. $9 \mathrm{G}$ ) is lined by a thin $(1-2 \mathrm{~cm}$ ) laminar calcrete that also penetrates downwards within the limestone. Both the micro-karst and calcrete indicate subaerial exposure of the lacustrine limestone, but under different conditions. The micro-karst probably formed under more humid conditions when after exposure and early lithification of the limestones, infiltrating rain and surface water caused dissolution. In contrast, calcrete formed under more arid conditions with scarce surficial water. Thus, the association of microkarst with calcrete is clear evidence of a compound sedimentary discontinuity that reveals changes in water availability. 
(7) Carbonate mounds form parts of continuous bodies with flat bases and wavy tops (Fig. 9H). Their convex-up morphologies are about $4 \mathrm{~m}$ wide and $1 \mathrm{~m}$ high and bases lie gradually on the flat pebble breccias. These mounds are composed of sandy micrite containing some clay. They are reddish and show grey to green haloes, which are very irregular but with a vertical trend. These haloes are either isolated fragments of the sandy micrite or just discoloured areas of the reddish mudstones. The haloes are more prominent in the middle and upper parts of the mounds, which also show rootlets. The tops of these beds, although irregular, are very sharp, and depressions are overlaid by intraclasts and black pebble rudstones. The presence of carbonate mounds is not uncommon in marginal lacustrine deposits. In these settings, PérezJiménez (2010) described different types of mounds within the Madrid Basin, whose formation is driven by either shallow groundwater seepages or by modification of previous carbonate deposits via movements of underlying vertisols. Whichever the case, the result is the formation of brecciated and nodular limestones as described in the Amargosa Desert (Hay et al., 1986), where the growth of carbonate is displacive. Other mechanisms of mound formation consider the baffling effect of hydrophytic plants (Calvo et al., 1985). Most of the settings where mounds form, whether composed of calcite or dolomite, contain $\mathrm{Mg}$-rich clays (Mg-smectites and sepiolite). In the study case no evidence of seepages, vertisols or Mg clays was found. However, mottling and nodule morphology clearly point to the role of plants and their roots in bioturbating and fragmenting the lacustrine limestone, observed as vertically elongated irregular biomicrite fragments and by their baffling effect retaining carbonate or siliciclastic (red) mud.

(8) Clayey limestones with root mats and coated grains occur only towards the topmost of Unit II. This facies consists of limestones including intraclasts of different size and morphologies and irregular zones of softer red micrite due to the presence of clays (Fig. 9E). Coated grains and thin root mats are irregularly distributed in this facies, but most prominent at the top. Intraclasts diminish from base to top. This facies is among the more pedogenically modified of the study area. As described for similar sequences of the Teruel Graben (Alonso-Zarza and Calvo, 2000), it reflects the formation of a soil on the palustrine limestones. The imprint of the soil vegetation is clear due to the presence of both coated grains and thin root mats.

\subsection{Vertical facies arrangement}

Although the vertical facies arrangement is well exposed in several cuts of the quarry, we selected five sequences (Fig. 10) representing the main vertical facies successions. All of these sequences include at least one sedimentary discontinuity (SD) due to exposure of the previous lake deposits. Below each SD, different thicknesses of primary deposits are modified (MD).

Sequence 1 (Fig. 10) consists of biomicrites capped by a thin laminar calcrete-coated microkarst (SD), both conforming a very irregular topography with small depressions, cavities and highs. Overlying coarse intraclastic rudstones to floatstones also fill the holes and depressions, and pass vertically to finer-grained packstones showing cross-bedding overlain by biomicrites containing root traces and fenestral structures.

Sequence 2 is composed of biomicrites capped by rudstones composed of large oncoids. The topmost of the sequence is formed of mudstones to wackestones with packstone lenses showing crossstratification.

Sequence 3 shows the desiccation (SD) of the mottled limestones and subsequent formation of flat pebble breccias, which constitute the base of the carbonate mounds. Coarse intraclastic rudstones, also containing extraclasts, overlie the mounds and fill the depressions between contiguous mounds. At the top, wackestones with fenestral structures contain small intraclastic packstone lenses.

Sequence 4 (Fig. 10) has a lower part of strongly desiccated limestones, which are fully brecciated and give rise to a limestone totally comprised of relatively "in situ" limestone fragments showing normal grading (granular limestones). The top of this bed is irregular and orange in colour due to the presence of clays/iron oxides (SD). The topmost mudstones to wackestones make gradual diffuse contact with $\mathrm{SD}$, and bear small karst cavities.

Sequence 5 (Fig. 10) is composed of a lower term of wackestones that are cut at the top by thin root mats. The wackestones are overlain by angular intraclasts showing thin root mats on their boundaries. The top of the sequence is a complex bed formed of intraclasts and coated grains embedded in a red micritic-clayey matrix. Thin root mats are observed across the topmost bed.

\subsection{Interpretation of the vertical trends}

The sequences described reveal a wide variety of processes, water energies and sedimentary discontinuities occurring in these shallow water lakes. The discontinuity in sequence 1 records intensive dissolution processes and further incipient soil development. The new phase of lacustrine sedimentation took place under relatively high-energy conditions probably driven by the entrance of alluvial channels into the lake area and over an irregular topography. Many of the coarse sediments derived from the micro-karstified and/or desiccated limestones formed during subaerial exposure. Gradual decreases in the supply of intra- and extraclasts, as well as in the energy of the lake water allowed deposition of the finer-grained wackestones-packstones. The discontinuity in sequence 2 is also marked by exposure and development of root mats. Fragments of lake mudstones/wackestones that constitute the nuclei of large $(\mathrm{cm})$ coated grains also indicate brecciation and reworking of previous lacustrine deposits. These nuclei were later on coated by carbonate precipitated under microbial influence. The uppermost bed of this sequence reflects differences in both the energy of the water and supply of coarse-grained sediments. Sequence 3 is rather complex and contains two sedimentary discontinuities. The lower one (SD-1) displays desiccation and brecciation of the lacustrine limestones and the formation on SD-1 of flat pebble breccias. All clasts in this discontinuity arose from the immediately underlying limestone. The next sedimentary event would start at SD-1. However, it is important to note that the real exposure surface was situated above the flat pebble breccias. The sediments found between SD-1 and SD-2 consist of carbonate mounds, whose top is SD-2. Similarly to other sequences, the next sedimentation event was of higher energy, and its sediments were sourced from both intrabasinal and extrabasinal areas (upper carbonate and/or siliciclastics reliefs). Sequence 4 reflects the progressive desiccation of the lake (SD) and subsequent pedogenic modification of the lacustrine limestone, giving rise to nodular fabrics similar to those described by De Wet et al. (1998) in the Triassic of Pennsylvania. The fact that the SD is diffuse and somewhat gradual suggests that even if the new water body was relatively quickly installed, it preserved the irregular morphology of SD. Sequence 5, very probably represents one of desiccation and subaerial exposure of mthick carbonate bodies. In this sequence, we localized the SD-1 in the lower part, based on the relatively sharp contact between the limestones. However, it is likely that the entire sequence records a relatively long exposure period (SD-2) accounting for: root mat development, fragmentation of the limestone which included these root mats, formation of coated grains and more intense development of root mats at the top. The top also contains more clays, suggesting more intense soil formation on the limestones and an increase of the terrigenous supply.

\subsection{An example of the lateral facies arrangement}

The quarry cuts are such that we can observe lateral changes between facies in detail along distances of up to $50 \mathrm{~m}$. As an example, 
(1)

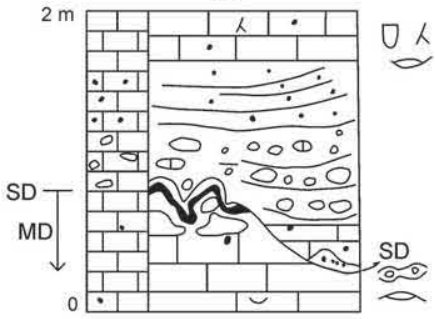

(2)

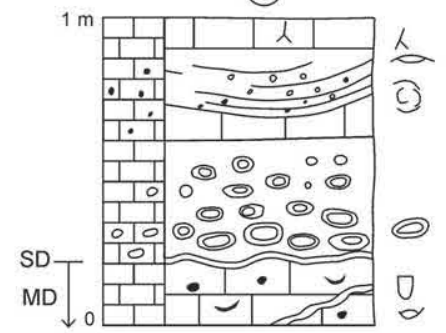

(3)

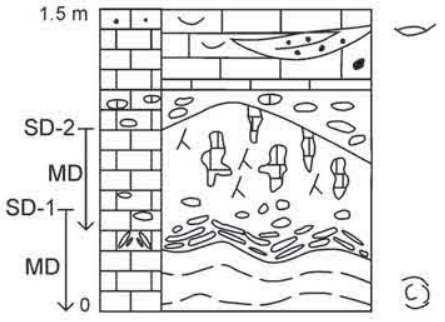

(4)
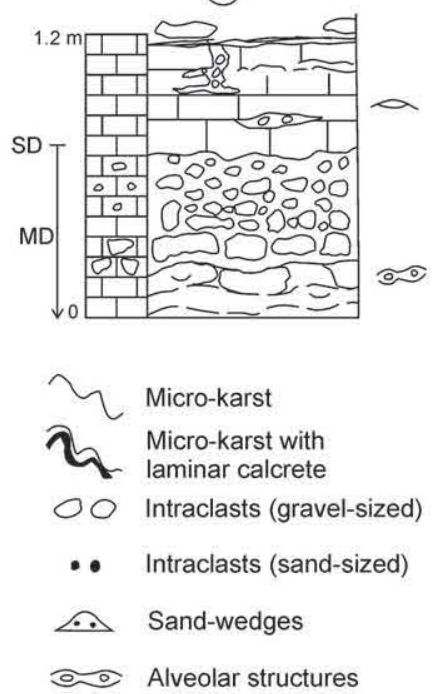

(5)
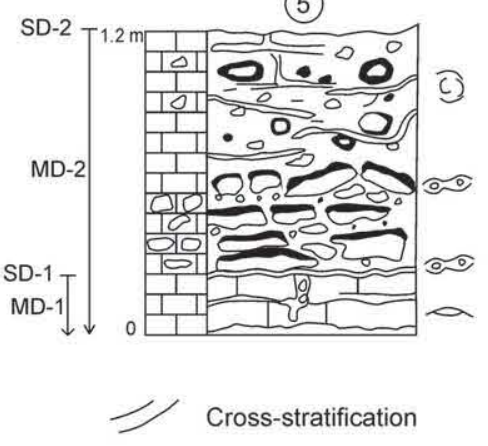

$\propto$ Fenestral structures

$\smile$ Bioclasts

- Black pebbles

人 Roots traces

$\square$ Trace fossil

Wackestones-packstones
Extraclasts
Mottling
Root mat
Breccia fragments with
thin root-mat
Coated grains (pedogenic)
Oncoids

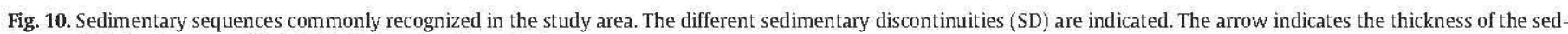
iment which has been modified (MD) during the discontinuity or exposure.

through the examination of eight lateral equivalent logs in study (panel 3), we prepared a detailed sketch of all the lateral and vertical transitions existing between the different facies (Fig. 11).

This panel (or bank) shows two main discontinuities. The lower one (SD-1) is relatively simple and across the quarry is characterized by the presence of desiccated limestones overlain by flat pebble breccias. The geometry of the surface is irregular showing both small-scale topographic differences and different measures of desiccation and/or root penetration.

The upper discontinuity in this panel (SD-2) is more complex and differs in both the characteristics of the exposure surface and in concurrent and subsequent lacustrine deposition (Fig. 11). Within the

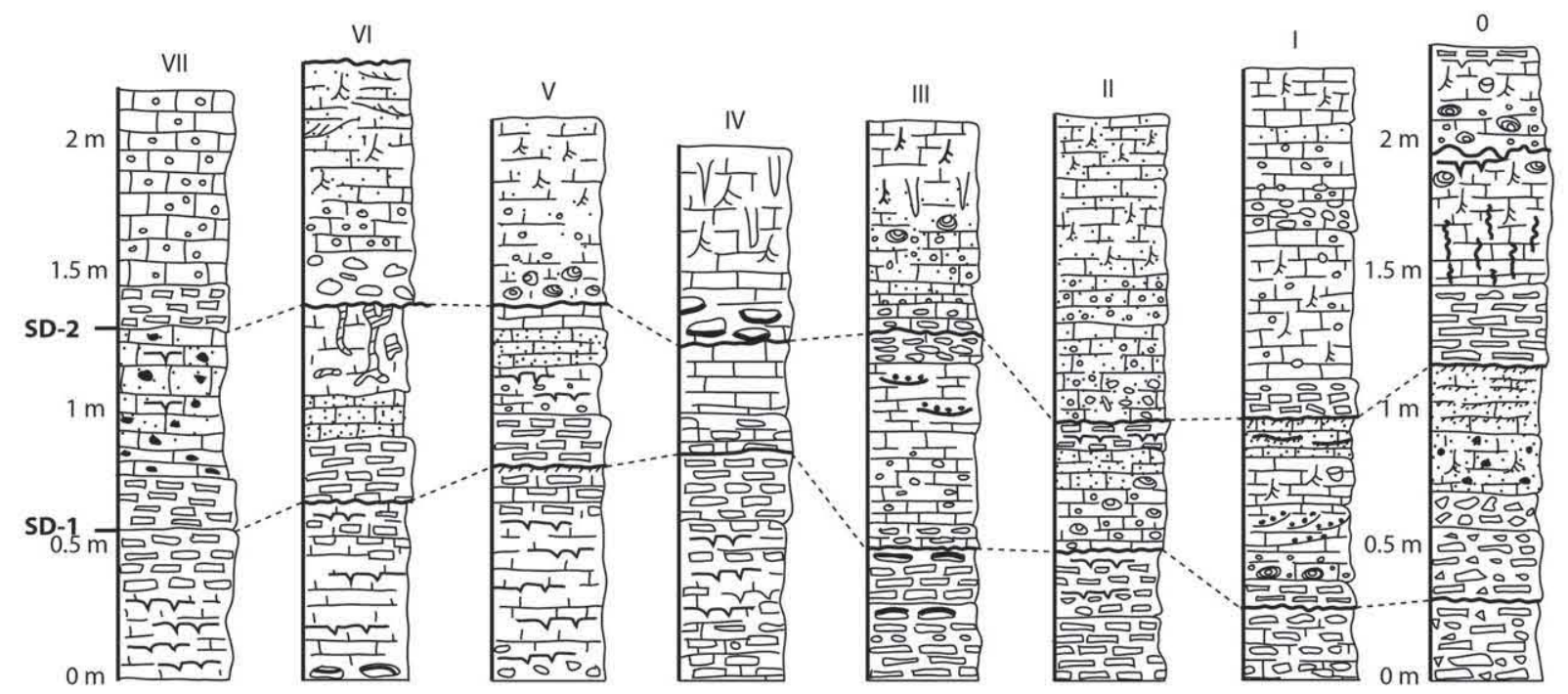

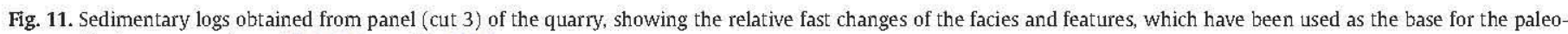
geographical reconstructions of Fig. 12. Legend in Fig. 5. 
exposure surface, the panel 3-VI area probably corresponds to a more elevated zone in which the micro-karst formed. A few meters to the south (panel 3-VII), the micro-karst disappears and passes to flat pebble breccias overlying desiccated mudstones. Northwards $(3-\mathrm{V})$ the surface is seen as a small depression but with few exposure features. It is very likely that sedimentation in this area was contemporary to exposure of the southernmost areas, and the only evidence of exposure is the large amount of intraclasts found in the depression. Further north there is no more evidence of the micro-karst and the discontinuity is marked by: (1) brecciated limestones overlain by flat pebble breccias occurring mostly in the relative highs of the surface, and/or (2) bodies up to $0.5 \mathrm{~m}$ thick composed of intraclastic rudstones (intraclastic gravels) present in the topographic lows. However, both may occur in the same place (3-III) with 1 situated beneath 2 .

Sedimentation after the upper discontinuity (SD-2) shows substantial differences that record the different water energies across really short distances (less than $10 \mathrm{~m}$ ). The distribution of the coarser sediments (intraclastic rudstones) seems to be controlled by the presence of small topographic depressions such as those in the vicinity of the micro-karst or in 3-II and 3-III. These lenses are channels and grade laterally to finer-grained wackestones and packstones.

\subsection{Interpretation of the lateral facies arrangement}

Many authors have identified the different facies associations within palustrine systems and described how they vary laterally in ancient deposits such as those of the Tertiary of the Ebro (Luzón et al., 2002) and Duero (Huerta and Armenteros, 2005) basins, but these common outcrops do not show the details we have described. In more recent Quaternary deposits, palustrine or wetland deposits have been frequently addressed through cores (Ashley et al., 2004; Alonso-Zarza et al., 2006) so some information on lateral facies changes is lost. Reuter et al. (2009) reported on variations in the strata geometries and facies architecture of recent palustrine/marl prairie deposits in Tanzania. However, the outcrop examined is not sufficiently indurated and only two main continental facies types were distinguished (palustrine and lacustrine). The study case shows the wide variety of palustrine facies that can be recognized in short distances and how complex their relationships can be.

Reconstruction of the palaeogeography of the SD- 1 of panel 3 (Fig. 12) reveals its similarity to that observed at present in different areas of Las Tablas de Daimiel (Fig. 13) and to that described by Armenteros and Daley (1998) for the Late Eocene of the Isle of Wight. This palaeogeography shows relative homogeneity in sedimentary and pedogenic processes operating across the entire study area, which probably reflects the infill of the lake accommodation space and subsequent exposure of wide areas (Fig. 12A).

In contrast, SD-2 and its overlying sediments define a complex morphology, in which relative highs were karstified, whereas low lying areas were strongly desiccated and penetrated by roots (Fig. 12B). Some low lying areas were preferential sites for the development of channels, in which most infill came from reworking of the underlying adjacent desiccated limestones. The presence of reworked deposits is in itself proof of a change produced at the lake-level, whether a fall or a rise, as described for the Balaton Lake in Hungary (Tullner and Cserny, 2003). In the present case, reworking is an indication of an initial level drop, with desiccation of large lake areas followed by a rise in the water level. Water was probably sourced by alluvial channels entering the lake. These channels transported and re-deposited fragments of the brecciated limestones. Variations in the type and grain size of the sediments deposited on the SD reflect different water level energies across the lake areas, controlled by the position of the main water influx or currents within the lake.
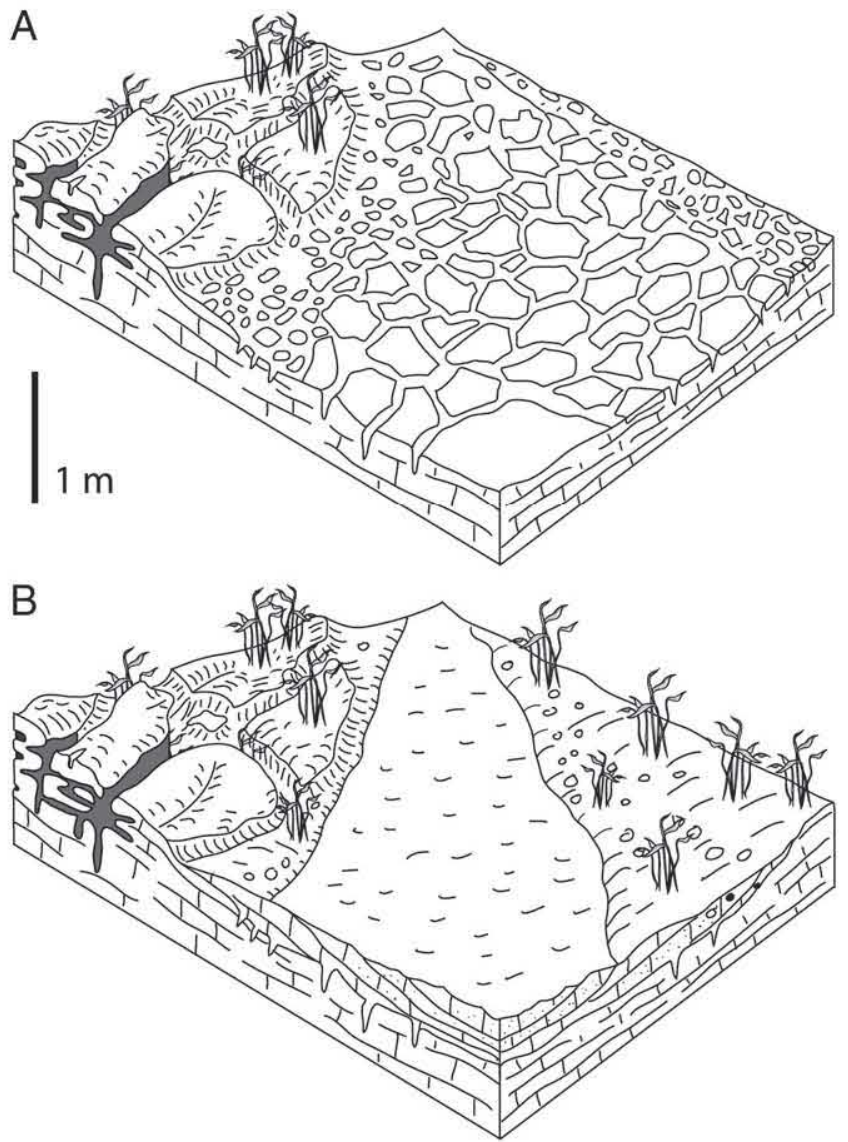

Fig. 12. Paleogeographical reconstructions. A: Sketch for one of the main sedimentary discontinuities (SD-2), the topography controlled the development of microkarst or flat pebble breccias. B. The rise of water level account for the sedimentation along wider areas. An important sediment supply comes from the previous exposed carbonate flats. The previous topography controlled the location of the channelized areas.

\section{Geochemistry}

\subsection{Elemental geochemistry}

Trace element distributions indicate only small amounts of most elements ( $\mathrm{Mg}, \mathrm{Mn}, \mathrm{Fe}, \mathrm{Al}, \mathrm{Si}$ ). The $\mathrm{MgCO}_{3} / \mathrm{CaCO}_{3}$ and $\mathrm{FeO} / \mathrm{CaO}$ ratios obtained are provided in Fig. $14 \mathrm{~A}$ and $\mathrm{B}$. $\mathrm{Mg}$ contents indicate that, in all cases, calcite is LMC, with only small differences between the different components analysed. Iron appears mostly in coatings and in some infills within the microspar, and shows greater variation than $\mathrm{Mg}$, but in general, the calcite is also Fe-poor.

\subsection{Stable isotopes}

The 58 samples analyzed in total were visually assigned to specific facies and/or components (Fig. 15A) and also obtained from welldefined panels $(1,3,5,6$ and 7$)$ of the section (Fig. 15B). We were therefore able to differentiate between: (1) generally non-mottled limestones, (2) mottled limestones, (3) clayey limestones, (4) intraclast nuclei and (5) microbial laminations. The mean $\delta^{13} \mathrm{C}$ value recorded for the samples was -4.60 , and mean $\delta^{18} 0$ was -6.55 . These values are similar to those frequently reported for freshwater palustrine carbonates (Platt, 1989; Arenas et al., 1997). Overall, values showed no covariation possibly indicating the lakes were hydrologically open (Talbot, 1990; Valero Garcés et al., 1997; Utrilla et al., 1998) or the input of groundwater into the lakes (Quade et al., 1995; Dunagan and Turner, 2004). The limited spread of $\delta^{18} \mathrm{O}$ (Fig. 15A, B) may suggest fixed lake water compositions (Talbot, 1990). Tandon and Andrews 
(2001) examined a large set of isotope data from palustrine carbonates and also found an overall narrow range of $\delta^{18} \mathrm{O}$ values and wider range of $\delta^{13} \mathrm{C}$.

The differences observed here in isotope signatures in the different panels and/or sequences examined, suggest that in spite of homogenization by diagenesis or reworking, part of the isotopic signature is still preserved, especially in terms of the carbon values recorded. The samples obtained in panel six represent the least pedogenically modified lacustrine deposits, and so their isotope values more reflect the lacustrine primary signal than the effects of pedogenesis, diagenesis or reworking. The values obtained in panel 1 partly overlap those of panel 6, except for 3 samples with lighter carbon, which reflects the pedogenic processes and/or the SD of the middle part of the panel. The panel 3 samples display heavier carbon values and higher variation in oxygen values. The lack of any trend within this group of samples is probably a reflection of the complex sedimentary (recycling), pedogenic and diagenetic processes occurring in these limestones (see interpretation above). In panel 7, the oxygen data show little spread, -6.5 , and values that represent the isotope composition of diagenetic fluids derived from meteoric waters (Anadón et al., 2000). The lighter carbon isotope values found in this panel 7 point to significant pedogenic processes affecting initial deposits, as well as the effect on plant respiration, which promoted ${ }^{12} \mathrm{C}$ enrichment of the resulting carbonate (Dunagan and Driese, 1999; Tanner, 2000) as observed for many of the coatings (Fig. 15A). Apart from coatings, the rest of the facies/components have similar isotope signatures and no differences were detected between intraclasts and their sources (mottled or non-mottled palustrine limestones). The stable isotope data within each panel show no clear vertical trend (Fig. 16).

Interpreting isotope data for lake-margin environments (DeoCampo, 2010) is difficult because of a lack of clear trends. This may be due to the imprints of common meteoric diagenetic processes affecting these carbonates and causing the loss of primary signatures and homogenization of data (Alonso-Zarza, 2003). Similarly, Bera et al. (2010) noted that burial diagenesis modified isotope signatures of Oligocene continental carbonates from the Himalayas, but that some of the initial signatures were preserved. Besides diagenesis, we should mention that most of the primary deposits examined here have been substantially reworked determining that the isotope composition of these palustrine deposits will reflect: the composition of the primary lacustrine deposition, the
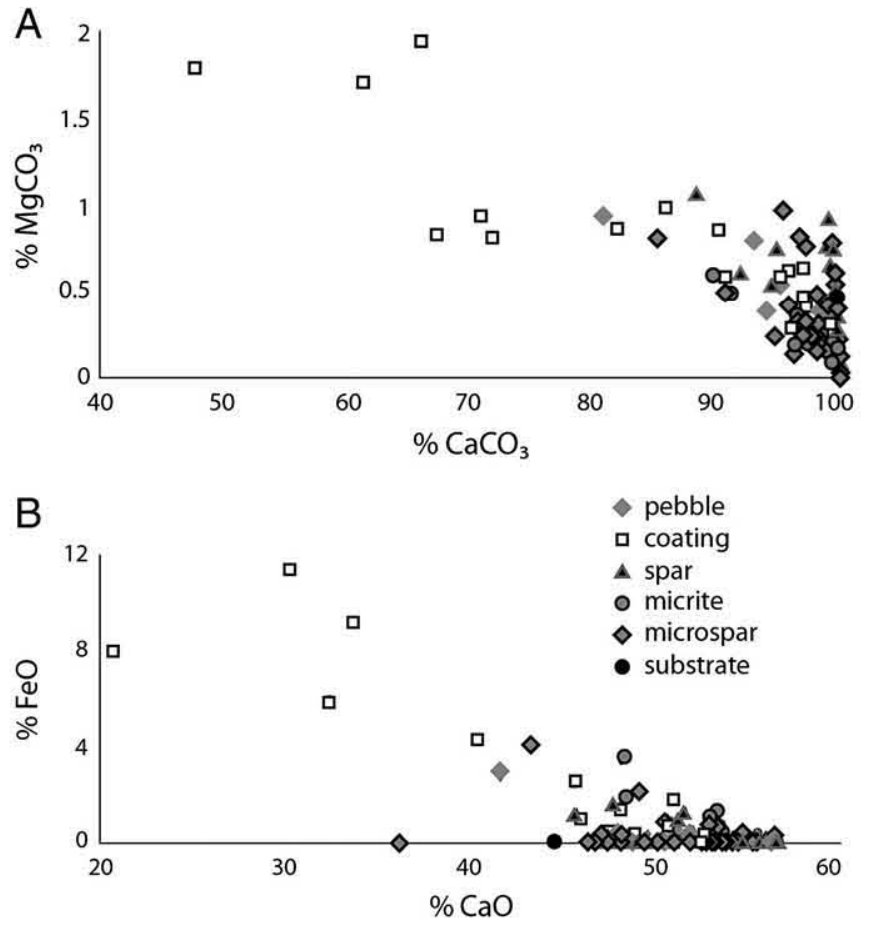

Fig. 14. A. $\mathrm{MgCO}_{3} / \mathrm{CaCO}_{3}$ ratios of different features of the palustrine limestones. B. FeO/ $\mathrm{CaO}$ ratio of some of the features, only some stained, spotty, areas contain more iron.

mixing of carbonate grains formed by different processes or sources (oncoids, intraclasts, bioclasts) and, obviously, the effects of pedogenesis and/or diagenesis.

\section{Discussion}

6.1. Record and significance of sedimentary discontinuities: morphological pahustrine stages

The variety of sedimentary discontinuities observed in the study deposits reflects the complex processes operating in these environments,

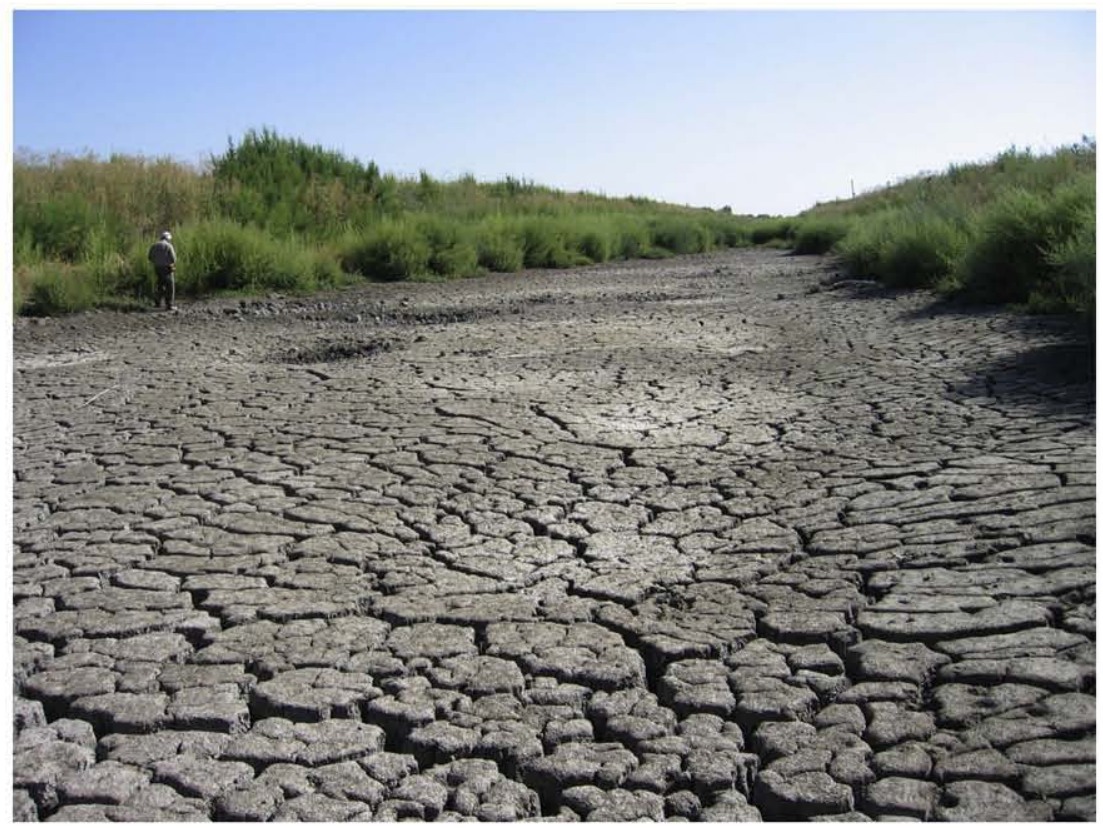

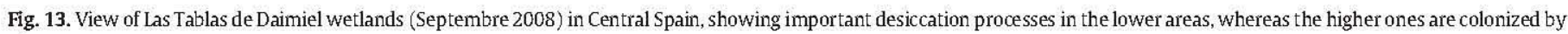
plants. 


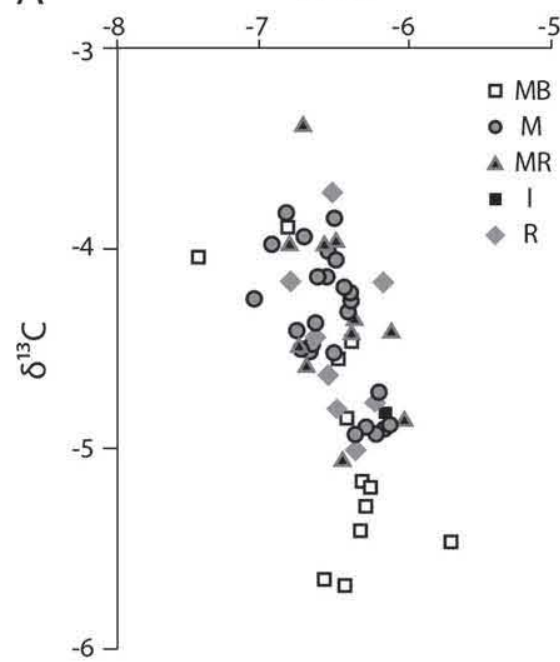

B

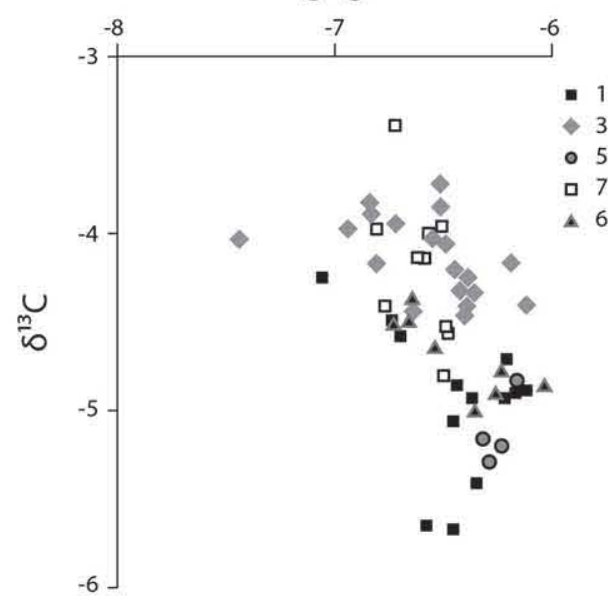

Fig. 15. Cross plot of $\delta^{18} \mathrm{O}$ versus $\delta^{13} \mathrm{C}$ for the palustrine carbonates of Unit II of the Teruel Graben. A. Values of the different facies/features (see Fig. 5) are shown. MB: microbial laminations M: Non-mottled limestones, MR: mottled limestones, R: clayey limestones, I: intraclast nuclei.B. Values for different panels.

and record time of no sedimentation, subsequent pedogenic and diagenetic processes and erosion, all occurring very close in time. We consider that when a sedimentation surface (TS1) has a significant exposure the top of the sedimentation surface (TS1) marks the sedimentary discontinuity (SD), and thus pedogenic and diagenetic processes advance downwards from TS1 (Fig. 17). The result of this is the modification of the primary sediment (LPS-1) below TS1. MD (modified primary deposit) is considered a whole exposure profile, which should be compared to calcrete, soil or even karst profiles and whose top corresponds to the exposed sedimentary surface (SD or TS).

The characteristics and thickness of the MD will give us an idea of both the time of exposure and sequence of the processes occurring within the palustrine environment. Hence several palustrine morphological stages can be identified in the study area.

Stage 0 indicates that the lacustrine primary sediment (LPS-1) has undergone no modification. The exposure time is 0 . Stage I occurs when the sediment is exposed and processes of desiccation, mottling and root penetration modify the LPS-1. Some trace fossils and mottling can develop at this stage. Only the upper part of the LPS is modified. Stage II is characterized by strong brecciation by both desiccation and roots leading to the formation of flat pebble breccias. A considerable thickness of the LPS is modified (MD), although in the lower part only desiccation features and mottling can be appreciated.
In Stage III, the fabric of the top of the LPS is totally transformed: intraclasts are unconnected, they may have lost their flat morphology and on occasion they appear embedded in a yellowish/reddish matrix containing some clays, either formed within the soil or infiltrated. Some intraclasts show laminar coatings. Stage IV comprises thin root mats and coated grains embedded in a micrite-clayey matrix at the top. At the base, flat pebble breccias, in which some of the clasts are partially coated by root mats, overlay desiccated limestones, also harbouring thin root mats. The fabric of the entire LPS is totally changed from base to top. We detected no further morphological stages, but it is possible to speculate that during a following Stage V, a thick and more continuous root mats would have developed on the flat pebble breccias to form a thick laminar calcrete.

Profile development may be interrupted by sedimentation, erosion, or both. When this occurs in stages II or III, three main situations may arise (Fig. 17):

(1) The renewal of sedimentation under relatively low-energy conditions causing the deposition of lacustrine primary sediment (LPS-2) and preserves the underlying sequence/profile.

(2) Erosion of part of the profiles, commonly the softer ones consisting of intraclasts and flat pebble breccias. Eroded limestone fragments could be re-deposited in nearby areas under highenergy conditions. Part of the profile is lost, corresponding to the time of sedimentation and time of subaerial exposure. The only record of all these processes is the presence of the intraclasts rudstones on the erosion surface (in many cases difficult to identify).

(3) Erosion of part of the profiles and renewal of sedimentation under low-energy conditions. In this case, LPS-2 directly lies on LPS-1, and it is impossible to interpret the stage of development of the eroded profile. This situation is relatively common in the sedimentary record, and unless the outcrop is clear and the erosion surface can be seen, these sequences can be misinterpreted as continuous sedimentary sequences.

We propose these morphological stages based on the main characteristic features observed, such as the presence of flat pebble breccias and/or intraclasts. Variations in these stages exist including the presence of micro-karst (Fig. 10-1), which may be tentatively considered as Stage III or IV, but in situations in which the main process operating is dissolution. Other variations include the carbonate mounds (Fig. 10-3) overlain by intraclasts, which we assigned to Stage II, but are followed by erosion and sedimentation of the surrounding carbonate flats.

The morphological stages of development within palustrine sequences or deposits have been addressed only on a few occasions to compare them with those commonly used in calcretes (Gile et al., 1966; Machette, 1985). In the general model, the different palustrine facies are the result of varying extents of pedogenic modification of the primary lacustrine deposits (Alonso-Zarza, 2003), which of course gives a relative idea of time. Other models propose different morphological stages for the transition between calcretes and palustrine deposits (Huerta and Armenteros, 2005) and also include groundwater calcretes (Armenteros and Huerta, 2006). Platt and Wright (1992) provided a simplified exposure index for freshwater palustrine environments. This index indicates the percentage of time over which the sediment surface is exposed and so palustrine features (calcrete, micro-karst, desiccation cracks, etc.) may develop under different indices. This model has been widely used (see Marty and Meyer, 2006), but it should be considered that it is based on the observation of specific features and the time considered is the hydroperiod (the number of flood days in a year). Palustrine features form under exposure indices between 30 and 70\% (Platt and Wright, 1992; Marty and Meyer, 2006) with a mean of $50 \%$.

Based on the age provided by micromammal sites and considering the mean thickness of Unit II (van Dam, 1997; Garcés et al., 1997), the 


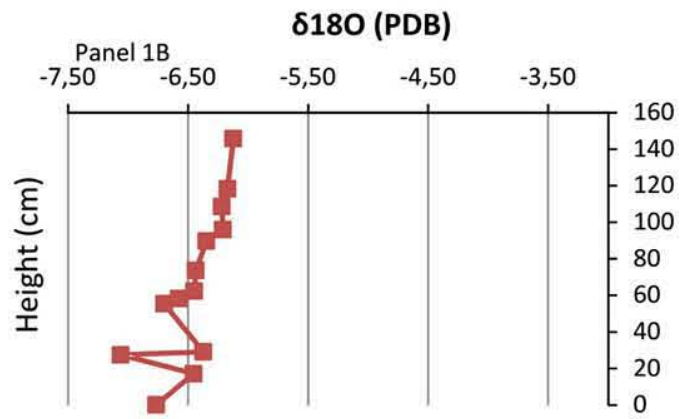

Panel 3
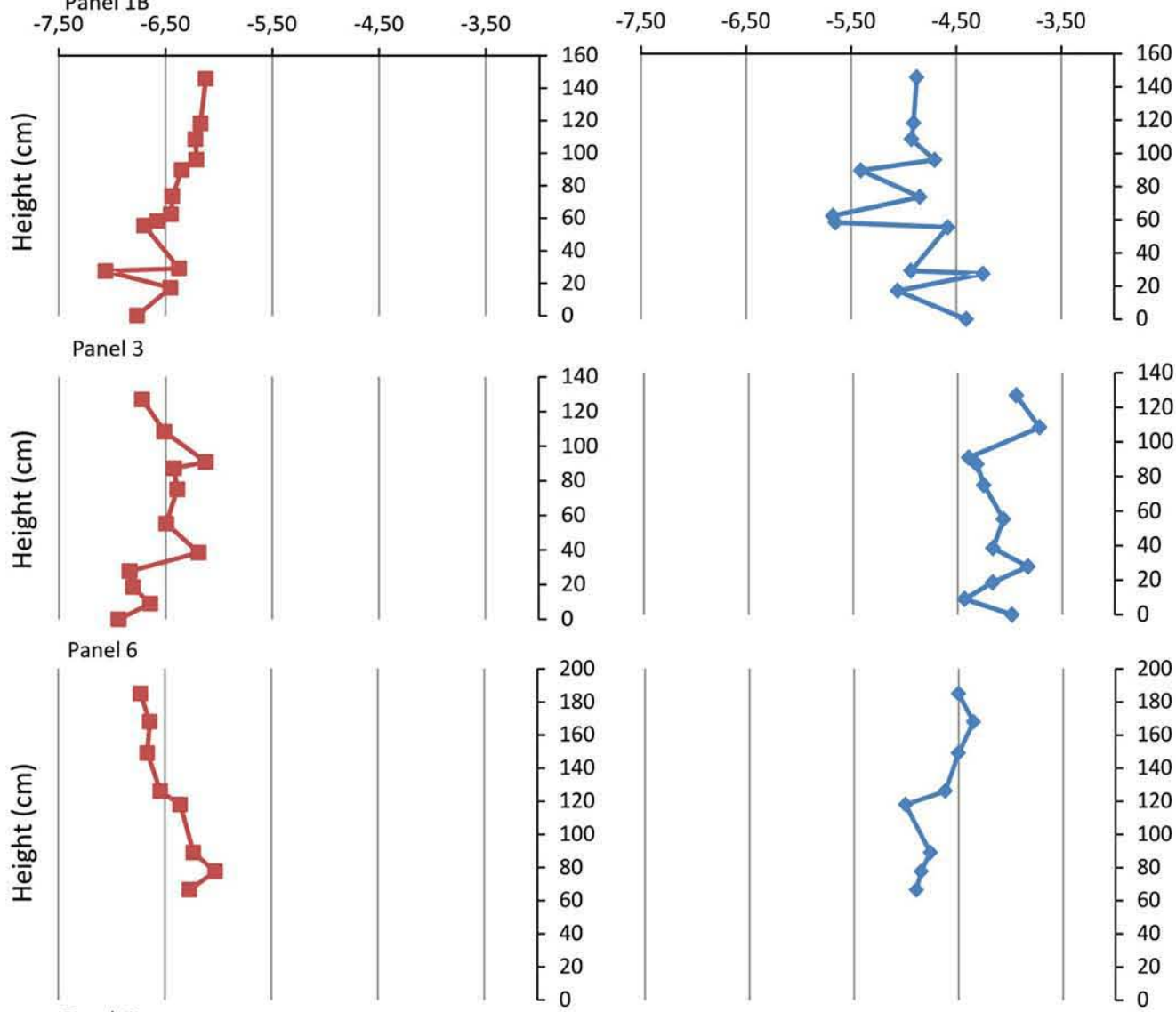

Panel 7
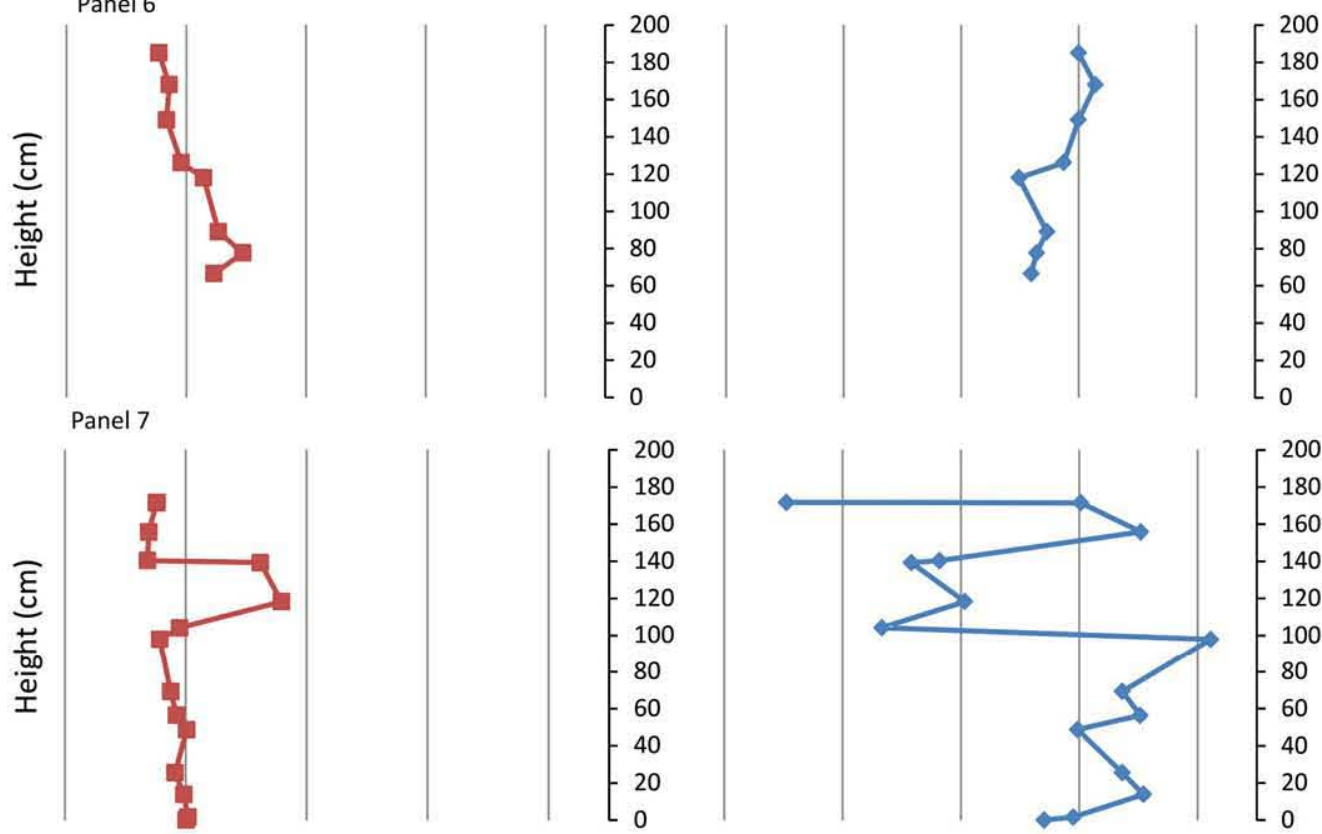

$\left[\begin{array}{l}200 \\ 180 \\ 160 \\ 140 \\ 120 \\ 100 \\ 80 \\ 60 \\ 40 \\ 20 \\ 0\end{array}\right.$

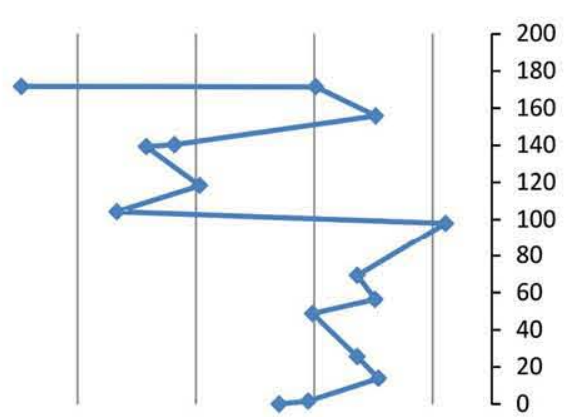

Fig. 16. A. Vertical trends of $\delta^{18} \mathrm{O}$ and $\delta^{13} \mathrm{C}$ in panels $1,3,6$ and 7.

rough estimate of sediment accumulation for this unit is $25 \mathrm{~mm}$ / $1000 \mathrm{yr}$. This means the formation of $1 \mathrm{~m}$ in $40,000 \mathrm{yr}$, which will include the sedimentation, exposure and erosion times. In addition, if we take into account an average exposure index of $50 \%$, this will mean 20,000 yr of sedimentation and $20.000 \mathrm{yr}$ of exposure time and subsequent modification. Since the most common stage represented in the study area is Stage III, we consider this morphological stage to have lasted around $40,000 \mathrm{yr}$ (including both sedimentation and subaerial exposure).

The morphological stages we propose complete existing models and enable us to trace not just one facies but the overall progression of the sequence and/or profiles over space and time, making them comparable to the chronosequences so commonly used for carbonate and non carbonate soils. Stages I and II will have formed over periods shorter than $40,000 \mathrm{yr}$, whereas IV and V, would represent longer periods. These values cannot be taken as absolute, but give a good idea of the range of time represented by the vertical sequences described. They also allow us to infer that they probably represent periods of tens to thousands of years.

\subsection{Source, production and recycling of carbonate}

The carbonate supply of these shallow lakes is easily explained given the high carbonate contents of the Teruel Graben Mesozoic highlands. Carbonate rocks in the hinterland favour the accumulation of carbonate deposits in a nearby lake basin, independently of climate (GierlowskiKordesch, 2010). Carbonate is carried in surficial waters either as ions or clasts, but also in groundwaters as ions. Lakes seems to be mostly fed by surface run-off, whereas wetland have a preferably groundwater input (Dunagan and Turner, 2004). However, both mechanisms may be combined and additional water supplied by sheet-flows or rivers should also be considered. Carbonate deposition within lakes may be attributed to: (1) chemical inorganic precipitation due to oversaturation (Deocampo, 2010), (2) biogenic production such as the shells of bioclasts or biogenically induced precipitation under the influence of microbes, amongst others, (3) clastic input, and (4) aeolian supply (GierlowskiKordesch, 2010). The first three mechanisms explain most carbonate accumulation in lakes over the world, being the aeolian input more difficult to prove (Gierlowski-Kordesch, 2010). In the Teruel Basin the chemical 


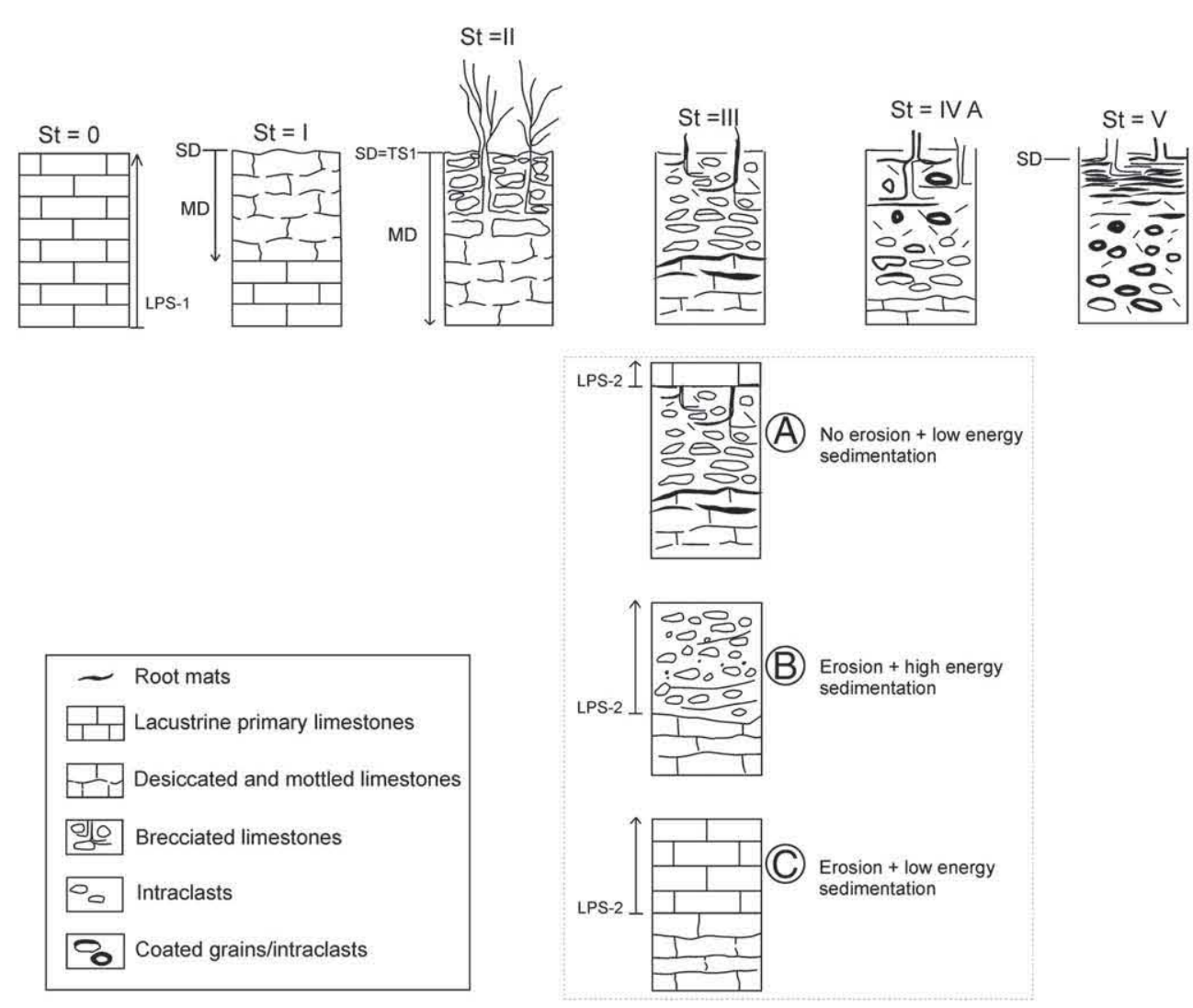

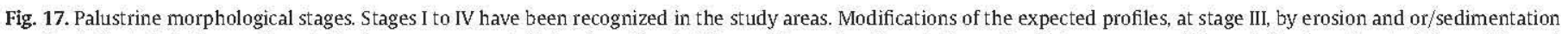

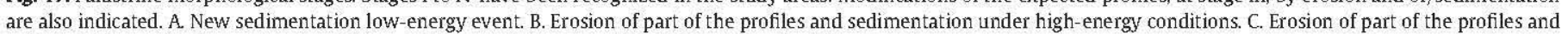
sedimentation under low-energy conditions, in this case it may very difficult to outline the SD.

inorganic and biogenic production of carbonate is evidenced by both the high micrite contents of these carbonates and the continuous presence of grains such as bioclasts or oncoids. The clastic input of intra- and extrabasinal carbonate to the lakes of the Tortajada area is easily recognizable in the coarser-grained deposits. Extrabasinal clasts were sourced from the surrounding Mesozoic carbonates and constitute a minor amount (less than 20\%) in comparison with intrabasinal clasts. The high amounts of intrabasinal clasts in the study area reveal the importance of the recycling of previously deposited carbonates. In addition to coarse clasts, some of the intra and extrabasinal carbonates were transported either as micrite-sized particles and ions, and later deposited either as laminated or graded micrite (coarser-sized) within the different types of cavities, or as inorganic biogenically precipitated micrite (finer-sized).

Similar to the situation commonly described in calcretes formed in alluvial deposits (Marriott and Wright, 1993; Khadkikar et al., 1998; Gómez-Gras and Alonso-Zarza, 2003), reworked lacustrine/palustrine sediments are proof of the loss of some of the primary sedimentary record of the Tortajada lakes, and thus their formation processes have to be taken into account when interpreting the sedimentary evolution of the lacustrine basin.

\subsection{Main controls on palustrine deposition: tectonism and climate}

In continental basins situated large distances from the sea, the main allocyclic factors controlling sedimentation are tectonism and climate. These factors interact to control potential accommodation space (mostly tectonic) and sediment + water supply (mostly climatic) (Carroll and Bohacs, 1999; Bohacs et al., 2000).

In the study area, the position of the lakes and their morphology were controlled by the situation and rates of movement of the main faults that created the accommodation space for water bodies. The lacustrine system was asymmetric with its depocentre adjacent to the main fault. Similar situations are common in lacustrine rift basins, where thicker deposits occur adjacent to the main fault, as described for the carbonate Cretaceous Castellar Formation of the Iberian Ranges, Spain (Meléndez et al., 2009) or the mostly siliciclastic deposits of the Triassic Ischigualasto-Villa Unión Basin in Argentina (Melchor, 2007).

Recent studies have calculated the average vertical slip rates for the main extensional faults of the central-eastern Iberian Chain (Simón, et al., in press). According to these studies the fault bounding the basin in the study area (Sierra del Pobo fault) would have moved about $82 \mathrm{~m}$ during the sedimentation of Unit II (9-7 Ma), creating so enough accommodation space for deposition of Unit II (up to $50 \mathrm{~m}$ thick). Compaction was not significant because of very shallow burial, so the preserved thickness of Unit II records sedimentation, subaerial exposition periods, erosion and recycling of the sediments. That means that more that $50 \mathrm{~m}$ of sediments were produced. A crude estimation, considering an average exposure index of $50 \%$, would indicate that if sedimentation would have been continuous, about $100 \mathrm{~m}$ of sediments could have been deposited during 9 to $7 \mathrm{Ma}$ ago. This estimation, although imprecise, is not very different of the vertical movement of the fault and so of the created accommodation space.

In sequence stratigraphy terms of continental basins, the carbonate deposits of the Tortajada area correspond to stages of low activity of alluvial/fluvial systems (Alonso-Zarza, 2003). The low activity pattern is controlled by tectonism or climate or both. Climate would mostly control water supply whereas tectonism have a major role in sediment supply. Low alluvial activity would favour the formation of vertically stacked palustrine sequences, such as those described in the Cretaceous Rupelo Formation (Platt, 1989). In these settings, carbonates onlapping the hinterland, as recognized in the study area or in the Intermediate Unit of the Madrid Basin (Alonso-Zarza et al., 
1992), are common. This low activity pattern situation has been also observed in the Plio-Pleistocene of the Guadix Basin, where its Unit VI consisting of a thick palustrine carbonate sequence was deposited as the result of a decrease in siliciclastic input and an increase in clastic carbonate input (Plá-Pueyo et al., 2009). Thus, we should stress that the low activity pattern situation may be more complex than envisaged since: (1) the data provided by the Guadix Basin indicate that carbonate clastic input may contribute to palustrine sedimentation, so low alluvial activity could only refer to siliciclastic systems, and (2) in the study case, part of the sediment supply comes from the reworking of previous lacustrine intrabasinal deposits, so the recycling of sediments has to be considered within the framework of this low activity pattern.

Climate seems to play an important role in short-term sedimentary sequences (De Wet et al., 2002; Khalaf and Gaber, 2008), though short-term subsidence episodes should also be considered (Huerta and Armenteros, 2005). The short-term (metre-scale) sequences shown in Fig. 10 could be the result of climate or tectonic changes. Close by and of the same age, the short-term lacustrine sequences of the Calatayud Basin have been interpreted as corresponding to astronomical precession cycles (Abdul-Aziz et al., 2000) and would therefore represent some 20,000 yr. Luzón et al. (2002) also argue that these cycles can be found in offshore lacustrine subenvironments, but they cannot be discerned in shallowing sequences in marginal lake environments. In the study case, the different palustrine morphological stages clearly indicate different times of formation for each stage and these times were probably longer, even for stages I or II, than the average $20,000 \mathrm{yr}$ of precession cycles. All our shortterm sedimentary sequences (Fig. 10) reflect a sudden increase in the water table followed by the subsequent formation of a shallow water lake that was filled by different types of lacustrine sediments (ranging from rudstones to wackestones). These sediments were pedogenically modified after their exposure. Similar sequences in this basin (Alonso-Zarza and Calvo, 2000) and in the Cretaceous of the Serranía de Cuenca (Gierlowski-Kordesch et al., 1991) have been interpreted to be the result of subsidence pulses due to tilting of the basin floor, followed by short-term periods of tectonic quiescence. Hence, very probably neither morphological stages nor shortterm sequences correspond to climatically driven cycles but rather to short-term subsidence episodes within a dominant extensional regime. This is interpretation is in good agreement with the average estimations of vertical movement of the main fault and sedimentation thickness. In addition the different morphological stages recognised formed along very different period of times so it is difficult to explain their formation as due to cyclically-controlled process, as the case of climatically driven cycles.

Climate was important as it affected the precipitation rate of carbonates whether inorganic or biogenic (Kelts and Hsü, 1978; Verrecchia, 2007). Very arid or very humid climates do not favour the precipitation of carbonates in lakes, whereas semi-arid to subhumid climates with marked seasonality are a main requirement for the formation of palustrine carbonates (Platt and Wright, 1992; Tanner, 2000; Tanner, 2010). These general semi-arid to sub-humid conditions prevailed in the Teruel Graben during the Miocene (van Dam, 1997) favoured and controlled the formation of features such as micro-karst or thin laminar calcretes (Platt and Wright, 1992). However, it seems that some changes such as the wetter and cooler conditions at the top of Unit II, which have been indicated by the mammal-record (van Dam, 1997; Van Dam and Weltje, 1999), have not left a clear imprint in the facies/features nor in the isotope signals offered by the palustrine carbonates of the study area. This may be because: (1) climate differences were insufficient to cause significant changes in the sedimentary record, or (2) the climate changes responsible for the intense desiccation events observed in our sequences, which are easily comparable to the changes occurring at present in Las Tablas de Daimiel, were too short to leave an imprint in the faunal record. In addition, our narrow range of primary oxygen isotope values of around $-6.5 \%$ may not be considered a simple climate signature but rather a likely indication of the influence of meteoric waters during sedimentation, pedogenesis and diagenesis and recycling of the sediments.

\section{Conclusions}

The Miocene lacustrine carbonates of the Teruel Graben (Unit II) contain a suite of features and facies that allow a detailed analysis of the processes and main controls operating in palustrine environments. Primary lacustrine facies were modified by pedogenic and diagenetic processes to form palustrine facies and their features include tabular wackestones to packstone beds (low-energy) and crossbedded rudstones to floatstones (high-energy) with significant amounts of intraclasts. Pedogenic features include cracks, mottling, thin laminar calcretes, intraclasts, coated grains and trace fossils. Micro-karst, microspar, cements and staining by Fe/Mn oxides/hydroxides are considered mostly diagenetic features, although the real boundary between pedogenesis and diagenesis is difficult to establish in these settings. Palustrine facies comprise limestones with root traces, mottled limestones, brecciated limestones, granular limestones, flat pebble breccias, micro-karstified limestones with laminar calcretes, carbonate mounds, and finally, clayey limestones with root mats.

The vertical facies arrangement records the presence of different sedimentary discontinuities (SD) revealed by how much the primary lacustrine deposit was modified during exposure. According to this extent of modification, several different morphological stages of palustrine deposition were established, which in a way can be compared to the stages described for calcretes. Five main stages were defined. Stage I, is characterized by incipient mottling and brecciation. Stage II shows mottling and an intense brecciation giving rise to the formation of intraclast breccias, in which fragments mostly appear "in situ". In Stage III, the primary fabric completely changes; intraclasts have moved and may have lost their initial morphology. This stage III may be also characterized by the formation of micro-karst. Stage IV displays the presence of coated grains and thin root mats. Stage $V$, not observed in the study area, would show a thicker development of root mats. Chronological data available for the study area indicate that Stage III took some $40,000 \mathrm{yr}$ to form (including both sedimentation and subaerial exposure). Shorter periods would be required for Stages I and II, and longer for Stages IV and V.

Palustrine deposition was characterized by considerable lateral changes produced over small distances (tens of metres). Slightly elevated areas were found to undergo karstification, whereas lower ones suffered mostly desiccation and were preferable sites for intraclast formation and reworking. Topographic control was also important for the renewal of sedimentation. In low-land areas intraclasts-filled channels contributed to the partial infill of the depressions. Both lateral and vertical facies changes indicate that energy levels of palustrine systems can be relatively high, and so palustrine deposits can also form in high-energy ramp-like settings. In addition, the high- energy level and high production of intraclasts observed in the study system highlight the important role of sediment recycling in shaping the facies and infills of the lakes.

Tectonism and climate were the main factors controlling the basin infill, its facies and their vertical arrangement and perhaps even its geochemical signature. However, the roles of these two factors differed considerably as did their imprints on the sedimentary record. Dominant semi-arid to sub-humid climates provided the appropriate conditions for: a) carbonate precipitation within lakes, b) the supply of water, c) periods of intense desiccation, and d) the activity of vegetation to act as an important modifier of earlier sediments. However, we were unable to detect the imprint of climatic changes neither in the form of metre-scale sequences, nor in the geochemical signals of 
the limestones. Thus, it seems that these types of deposit are not good enough for detailed palaeoclimate studies. Tectonism within this halfgraben clearly controlled: a) the location of lacustrine depocentres, b) the stages of low activity of alluvial/fluvial systems (low activity pattern) and, c) the short-term, or metre-scale sedimentary sequences, which we interpret as a response to short subsidence pulses followed by periods of tectonic quiescence in which the lakes were infilled and, in cases, desiccated.

In short, palustrine carbonates in continental rift (semi-graben) basins seem to be very sensitive to short-term tectonic movements. Sub-humid to semi-arid climates are a requirement for the formation of palustrine carbonates similar to the described in this paper, however, the imprint of climate changes is difficult to detect in the sedimentary record of these carbonates.

\section{Acknowledgements}

This work was funded by projects CGL-2008-05584-C02-02 from the Spanish Ministerio de Ciencia e Innovación and CCG07-UCM/ AMB2299 from CM-UCM. Dr. I. Armenteros and an anonymous reviewer contributed to improve the paper. Anna Burton reviewed the English version of the manuscript. Mármoles Llorrens Company is thanked for the facilities given to work in the quarry.

\section{References}

Abdul-Aziz, H., Hilgen, F., Krijgsman, W., Sanz, E., Calvo, J.P., 2000. Astronomical forcing of sedimentary cycles in the middle to late Miocene continental Calatayud Basin (NE Spain). Earth and Planetary Science Letters 177, 9-22.

Alcalá, L., 1994. Macromamíferos neógenos de la fosa de Alfambra-Teruel. Instituto de Estudios Turolenses-Museo Nacional de Ciencias Naturales, CSIC, Teruel-Madrid $554 \mathrm{pp}$.

Alcalá, L. Alonso-Zarza, A.M., Álvarez, M.A., Azanza, B., Calvo, J.P., Cañaveras, J.C., van Dam, JA Garcés, M. Krijgsma, V. van der Meulen, A.J. Morales, J. Peláez, P. Pérez-González, A., Sánchez, S., Sancho, R., Sanz, E., 2000. El registro sedimentario y faunístico de las Cuencas de Calatayud-Daroca y Teruel. Evolución paleoambiental y paleoclimática durante el Neógeno. Revista de la Sociedad Geológica de España 13, 323-343.

Alonso-Zarza, A.M., 2003. Palaeoenvironmental significance of palustrine carbonates and calcretes in the geological record. Earth-Science Reviews 60, 261-298.

Alonso-Zarza, A.M., Calvo, J.P., 2000. Palustrine sedimentation in an episodically subsiding basin: the Miocene of the northern Teruel Graben (Spain). Palaeogeography. Palaeoclimatology, Palaeoecology 160, 1-21.

Alonso-Zarza, A.M., Wright, V.P., 2010. Palustrine carbonates. In: Alonso-Zarza, A.M. Tanner, L.H. (Eds.), Carbonates in continental settings: facies, environments and processes: developments in sedimentology, 61. Elsevier, Amsterdam, pp. 225-267.

Alonso-Zarza, A.M. Calvo, J.P., García del Cura, M.A., 1992. Palustrine sedimentation and associated features-grainification and pseudo-microkarst-in the Middle Miocene (Intermediate Unit) of the Madrid Basin, Spain. Sedimentary Geology $76,43-61$.

Alonso-Zarza, A.M., Dorado-Valiño, M., Valdeolmillos-Rodríguez, A., Ruiz-Zapata, M.B. 2006. A recent analogue for palustrine carbonate environments: the Quaternary deposits of Las Tablas de Daimiel wetlands, Ciudad Real, Spain. In: Alonso-Zarza, A.M., Tanner, L.H. (Eds.), Paleoenvironmental record and applications of calcretes and palustrine carbonates: Geological Society of America, Special Paper, 416, pp $153-168$.

Alonso-Zarza, A.M., Genise, J., Verde, M., 2011. Sedimentology, diagenesis and ichnol ogy of Cretaceous and Palaeogene calcretes and palustrine carbonates from Uruguay. Sedimentary Geology 236, 46-61.

Anadón, P., Moissenet, E., 1996. Neogene basins in the Eastern Iberian Range. In Friend, P.F., Dabrio, C. (Eds.), Tertiary basins of Spain. The stratigraphic record of crustal kinematics. : World and Regional Geology, 6. Cambridge Univ. Press, Cambridge, pp. 68-76.

Anadón, P., Cabrera, L., Juliá, R., Roca, E., Rosell, L., 1989. Lacustrine oil-shale basins in Tertiary grabens from NE Spain (Western European rift systems). Palaeogeography, Palaeoclimatology, Palaeoecology $70,7-28$.

Anadón, P., Utrilla, R., Vázquez, A., 2000. Use of charophyte carbonates as proxy indicators of subtle hydrological and chemical changes in marl lakes: example from the Miocene Bicorb Basin, eastern Spain. Sedimentary Geology 133, 325-347.

Anadón, P., Alcalá, L., Alonso-Zarza, A.M., Calvo, J.P., Ortí, F., Rosell, L., 2004. Cuenca de Teruel. In: Vera, J.A. (Ed.), Geología de España. Sociedad Geológica de EspañaIGME, Madrid, pp. 565-566.

Arenas, C., Casanova, J., Pardo, G., 1997. Stable-isotope characterization of the Miocene lacustrine systems of Los Monegros (Ebro Basin, Spain): palaeogeographic and palaeoclimatic implications. Palaeogeography, Palaeoclimatology. Palaeoecology $128,133-155$.
Armenteros, 1., Daley, B., 1998. Pedogenic modification and structure evolution in palustrine facies as exemplified by Bembridge Limestone (late Olocene) of Isle of Wight, southern England. Sedimentary Geology 119, 275-295.

Armenteros, I., Huerta, P., 2006. The role of clastic sediment influx in the formation of calcrete and palustrine facies: A response to paleogeographic and climatic conditions in the southeastern Tertiary Duero basin (northern Spain). In: AlonsoZarza, A.M., Tanner, L.H. (Eds.), Paleoenvironmental record and applications of calcretes and palustrine carbonates: Geological Society of America, Special Paper, 416, pp. 119-132.

Armenteros, I., Daley, B., García, E., 1997. Lacustrine and palustrine facies in the Bembridge Limestone (late Eocene, Hamshire Basin) of Isle of Wight, southern England Palaeogeography, Palaeoclimatology, Palaeoecology 128, 111-132.

Ashley, G.M., Maitima Mworia, J., Muasya, A.M., Owens, R.B., Driese, S.G., Hover, V.C. Renaut, R.W., Goman, M.F., Mathai, S., Blatt, S.H., 2004. Sedimentation and recent history of a freshwater wetland in a semi-arid environment: Loboi Swamp, Kenya, East Africa. Sedimentology 51, 1-21.

Ausseil, A.G.E., Chadderton, W.L., Gerveauz, P., Stephens, R.T.T., Leathwich, J.R., 2011 Applying systematic conservation planning principles to palustrine and inland saline wetlands of New Zealand. Freshwater Biology 56, 142-161.

Bera, M.K., Sarkar, A., Tandon, S.K., Samanta, A., Sanyal, P., 2010. Does burial diagenesis reset pristine isotopic composition in paleosol carbonates? Earth and Planetary Science Letters 300, 85-100.

Bohacs, K.M., Carroll, A.R., Neal, J.E., Mankiewicz, P.J., 2000. Lake-basin type, source potential, and hydrocarbon character: an integrated-sequence-stratigraphic-geochemical framework. In: Gierlowski-Kordesch, E.H., Kelts, K.R. (Eds.), Lake Basins through Space and Time: AAPG Studies in Geology, 46, pp. 3-34

Braissant, O., Guillaume, C., Aragno, M., Verrecchia, E.P., 2004. Biologically induced mineralization in the tree Milicio excelsa (Moraceae): its causes and consequences to the environment. Geobiology 2, 59-66.

Bustillo, M.A., Alonso-Zarza, A.M., 2007. Overlapping of pedogenesis and meteoric diagenesis in distal alluvial and shallow lacustrine deposits in the Madrid Miocene Basin, Spain. Sedimentary Geology 198, 255-271.

Calvet, F., Juliá, R., 1983. Pisoids in the caliche profiles of Tarragona (NE Spain). In: Peryt, T.M. (Ed.), Coated Grains. Springer, Berlin, pp. 73-79.

Calvo, J.P., Hoyos, M., García del Cura, M.A., 1985. "Mud-mounds" en sedimentos lacustres someros del Mioceno medio de la Cuenca de Madrid. Estudios Geológicos 41 25-31.

Carroll, A.R., Bohacs, K.M., 1999. Stratigraphic classification of ancient lakes: balancing tectonic and climatic controls. Geology 27, 99-102.

Chekroun, K.B., Rodríguez-Navarro, C., González-Muñoz, M.T., Arias, J.M., Cultrone, G., Rodríguez-Gallego, M., 2004. Precipitation and growth morphology of calcium carbonate induced by myxococcus xanthus: implications for recognition of bacterial carbonates. Journal of Sedimentary Research 74, 868-876.

De Wet, C., Yocum, D.A., Mora, C., 1998. Carbonate lakes in closed basins: sensitive in dicators of climate and tectonics: an example from the Gettysburg Basin (Triassic) Pennsylvania, USA. Role of Eustasy, Climate and Tectonism in Continental Rocks: SEPM Special Publication, 59, pp. 191-209.

De Wet, C., Mora, C.I., Gore, P.J.W., Gierlowski-Kordesch, E., Cucolo, S.J., 2002. Deposition and geochemistry of lacustrine and spring carbonates in Mesozoic rift basins, Eastern North America. Sedimentation in Continental Rifts: SEPM Special Publication, 73, pp. 309-325.

DeoCampo, D.M., 2010. The geochemistry of continental carbonates. In: Alonso-Zarza, A.M. Tanner, L.H. (Eds.), Carbonates in continental settings: geochemistry, diagenesis and applications. : Developments in Sedimentology, 62. Elsevier, Amsterdam, pp. 1-59.

Dunagan, S.P., Driese, S.G., 1999. Control of terrestrial stabilization on late Devonian palustrine carbonate deposition: Catskill Magnafacies, New York, U.S.A. Journal of Sedimentary Research 69, 772-783.

Dunagan, S.P., Turner, C.E., 2004. Regional paleohydrologic and paleoclimatic settings of wetland/lacustrine depositional systems in the Morrison Formation (Upper Jurassic), Western Interior, USA. Sedimentary Geology 167, 269-296.

Dunham, RJ., 1969. Early vadose silt in Townsed mound (reef), New Mexico. In: Friedman, G.M. (Ed.), Depositional Environments in Carbonate Rocks: Special Publication SEMP, 14, pp. 139-182

Esteban, M., 1972. Una nueva forma de prismas de Microcodium Elegans Glück 1912 y su relación con el caliche del Eoceno Inferior, Marmellá, provincia de Tarragona (España). Revista Instituto de Investigaciones Geológicas, Universidad de Barcelona 27, 65-81.

Freytet, P., 1973. Petrography and paleo-environment of continental carbonate deposits with particular reference to the Upper Cretaceous and Lower Eocene of Languedoc (Southern France). Sedimentary Geology 10, 25-60.

Freytet, P., Plaziat, J.C., 1982. Continental carbonate sedimentation and pedogenesisLate Cretaceous and Early Tertiary of southern France. Contributions to Sedimentology, 12. E. Schweizerbart'sche Verlagsbuchhandlung, Stuttgart. 213 pp.

Freytet, P., Verrecchia, E.P., 2002. Lacustrine and palustrine carbonate petrography: an overview. Journal of Paleolimnology 27, 221-237.

Garcés, M., Krijsman, W., Van Dam, J., Calvo, J.P., Alcalá, L, Alonso-Zarza, A.M., 1997. Late Miocene alluvial sediments from the Teruel area: magnetostratigraphy, mag netic susceptibility, and facies organization. Acta Geológica Hispánica 32, 171-184.

Genise, J.F., Melchor, R.N., Bellosi, E.S., Verde, M., 2010. Invertebrate and vertebrate trace fossils from continental carbonates. In: Alonso-Zarza, A.M., Tanner, L.H. (Eds.), Carbonates in Continental Settings: Facies, Environments and Processes: Developments in Sedimentology, 61. Elsevier, Amsterdam, pp. 319-369.

Gierlowski-Kordesch, E.H., 2010. Lacustrine carbonates. In: Alonso-Zarza, A.M., Tanner, L.H. (Eds.), Carbonates in Continental Settings: Facies, Environments and Processes: Developments in Sedimentology, 61. Elsevier, Amsterdam, pp. 1-102. 
Gierlowski-Kordesch, E., Gómez Fernández, J.C., Meléndez, N., 1991. Carbonate and coal deposition in an alluvial-lacustrine setting: Lower Cretaceous (Weald) in the Iberian Range (east-central Spain). In: Anadón, P., Cabrera, L., Kelts, K. (Eds.), Lacustrine facies analysis: Special Publication International Association of Sedimentologists, 13, pp. 109-125.

Gile, L.H., Peterson, F.F., Grossman, R.B., 1966. Morphological and genetic sequences of carbonate accumulation in desert soils. Soil Science 101, 347-360.

Gómez-Gras, D., Alonso-Zarza, A.M., 2003. Reworked calcretes: their significance in the reconstruction of alluvial sequences (Permian and Triassic, Minorca, Balearic Islands, Spain). Sedimentary Geology 158, 299-319.

Hay, R.L, Pexton, R.W., Teague, T.T., Kyser, T.K., 1986. Spring-related carbonate rocks, Mg clays, and associated minerals in Pliocene deposits of the Amargosa Desert, Nevada and California. Geological Society of America Bulletin 97, 1488-1503.

Huerta, P., Armenteros, I., 2005. Calcrete and palustrine assemblages on a distal alluvial-floodplain: a response to local subsidence (Miocene of the Duero Basin, Spain). Sedimentary Geology 177, 235-270.

Jaillard, B., 1987. Les structures rhizomorphes calcaires: Modéle de reorganisation des minéraux du sol par les racies. Thése, Univ. des Sciences et Techniques du Languedoc, Montpellier, $220 \mathrm{pp}$.

Jarosewich, E.J., Nelen, J.A., Norberg, J.A., 1980. Reference samples for electron microprobe analysis. Geostandards Newsletters $4,43-47$

Jones, B., 1992. Construction of spar calcite crystals around spores. Journal of Sedimentary Petrology 62, 1054-1057

Jones, B., Squair, C.A., 1989. Formation of peloids in plant rootlets, Grand Cayman, British West Indies. Journal of Sedimentary Petrology 59, 457-467.

Kelts, K.R., Hsü, K., 1978. Freshwater carbonate sedimentation. In: Lerman, A. (Ed.), Lakes-Chemistry, Geology, Physics. Springer, New York, pp. 295-323.

Khadkikar, A.S., Merh, S.S., Malik, J.N., Chamyal, L.S., 1998. Calcretes in semi-arid alluvial systems: formative pathways and sinks. Sedimentary Geology 116, 251-260.

Khalaf, F.I., Gaber, A.S., 2008. Occurrence of cyclic palustrine and calcrete deposits within the Lower Pliocene Hagul Formation, East Cairo District, Egypt. Journal of African Earth Sciences 51, 298-312.

Klappa, C.F., 1979. Lichen stromatolites: criterion for subaerial exposure and a mechanism for the formation of laminar calcretes (caliche). Journal of Sedimentary Petrology 49, 387-400.

Kosir, A, 2004. Microcodium revisited: root calcification products of terrestrial plants on carbonate-rich substrates. Journal of Sedimentary Research 74, 845-857.

Lafuente, P., Arlegui, L.E., Liesa, C.L., Simón, J.L, 2010. Paleoseismological analysis of an intraplate extensional structure: the Concud fault (Iberian Chain, Eastern Spain). International Journal of Earth Sciences, http://dxdoi.org/10.1007/s00531-010-0542-1.

Luzón, A., González, A, Muñoz, A., Sánchez-Valverde, B., 2002. Upper Oligocene-Lower Miocence shallowing-upward lacustrine sequences controlled by periodic and non-periodic processes (Ebro Basin, northeastern Spain). Journal of Paleolimnology $28,441-456$.

Machette, M.N., 1985. Calcic soils of southwestern United States. In: Weide (Ed.), Soil and Quaternary Geology of the Southwestern United States: Spec. Paper. Geological Society of America, 203, pp. 1-21.

MacNeil, A.J., Jones, B., 2006. Palustrine deposits on a Late Devonian coastal plain-sedimentary attributes and implications for concepts of carbonate sequence stratigraphy. Journal of Sedimentary Research 76, 292-309.

Marriott, S.B., Wright, V.P., 1993. Palaeosols as indicators of geomorphic stability in two Old Red Sandstone alluvial suites, South Wales. Journal of the Geological Society of London 150, 1109-1120.

Marty, D., Meyer, C.A., 2006. Depositional conditions of carbonate-dominated palustrine sedimentation around the K-T boundary (Faciês Rognacien, northeastern Pyrenean foreland, southwestern France). In: Alonso-Zarza, A.M., Tanner, L.H. (Eds.), Paleoenvironmental Record and Applications of Calcretes and Palustrine Carbonates Geological Society of America, Special Paper, 416, pp. 153-168.

Mazzullo, S.J., Birdwell, B.A., 1989. Syngenetic formation of grainstones and pisolites from fenestral carbonates in peritidal settings. Journal of Sedimentary Petrology 59, 605-611.

McCrea, J.M., 1950. On the isotopic chemistry of carbonates and a paleotemperature scale. Journal of Chemical Physics $18,849-857$

Melchor, R.M., 2007. Changing lake dynamics and sequence stratigraphy of synrift lacustrine strata in a half-graben: an example from the Triassic Ischigualasto-Villa Unión Basin, Argentina. Sedimentology 54, 1417-1446.

Meléndez, N., Liesa, C.L., Soria, A.R., Meléndez, A., 2009. Lacustrine system evolution during early rifting: El Castellar Formation (Galve sub-basin, Central Iberian Chain). Sedimentary Geology 222, 64-77.

Meléndez, A., Alonso-Zarza, A.M., Sancho, C, 2011. Multi-storey calcrete profiles developed during the initial stages of the configuration of the Ebro Basin's exorrheic fluvial network. Geomorphology 134, 232-248.

Moissenet, E., 1983. Aspectos de la neotectónica en la Fosa de Teruel. Geología de España, T. II. IGME, Madrid, pp. 427-446.

Moissenet, E., 1989. Les fossés néogènes de la Chaîne Ibérique : leur évolution dans le temps. Bulletin de la Société Geologique de France, série 8 (5), 919-926.

Parraga, J., Rivadeneyra, M.A., Martin-García, J.M., Delgado, R., Delgado, G., 2004. Precipitation of carbonates by bacteria from a saline soil, in natural and artifitial soil extracts. Geomicrobiology Journal 21, 55-66.

Pérez-Jiménez, J.L., 2010. Sedimentología, silicificaciones y otros procesos diagenéticos en las Unidades Intermedia y Superior del Mioceno de la Cuenca de Madrid (zonas NE, NW y W). PhD Thesis. Universidad Complutense de Madrid, 336pp.

PiPujol, M.D., Buurman, P., 1997. Dynamics of iron and calcium carbonate redistribution and palaeohydrology in middle Eocene alluvial paleosols of the southeast Ebro Basin margin. Palaeogeography, Palaeoclimatology, Palaeoecology 134, 87-107.

Plá-Pueyo, S., Gierlowski-Kordesch, E.H., Viseras, C., Soria, J.M., 2009. Major control son sedimentation during the evolution of a continental basin: Pliocene-Pleistocene of the Guadix Basin (Betic Cordillera, southem Spain). Sedimentary Geology 219, 97-114.

Platt, N.H., 1989. Lacustrine carbonates and pedogenesis: sedimentology and origin of palustrine deposits from the Early Cretaceous Rupelo Formation. W Cameros Basin, N Spain. Sedimentology 36, 665-684.

Platt, N.H., Wright, V.P., 1992. Palustrine carbonates at the Florida Everglades: towards an exposure index for the fresh-water environment. Journal of Sedimentary Petrology $62,1058-1071$.

Plaziat, J.C., 1984. Le problème des Microcodium: une mise au point. In: Le Domain pyrénéen de la Fin du Crétacé à la fin de l'Eocene: Stratigraphie, Paléoenvironnements et Êvolution paléogéographique. Thése, Universié Paris-Sud II, pp. 637-662.

Plaziat, J.C., Freytet, P., 1978. Le pseudo-microkarst pédologique: un aspect particulier des paléo-pédogenèses développées sur les dépôts calcaires lacustres dans le Tertiaire du Languedoc. Comptes Rendus de l'Academie des Sciences, Paris 286, 1661-1664.

Quade, J., Chivas, A.R., McCulloch, M.T., 1995. Strontium and carbon isotope tracers and the origins of soil carbonate in South Australia and Victoria. Palaeogeography, Palaeoclimatology, Palaeoecology 113, 103-117.

Reuter, M. Piller, W.E., Harzhauser, M., Kroh, A., Berning, B., 2009. A fossil evergladestype marl praire and its paleoenvironmental significance. Palaios 24, 747-755

Rubio, J.C., Simón, J.L., 2007. Tectonic subsidence v. erosional lowering in a controversial intramontane depression: the Jiloca basin (Iberian Chain, Spain). Geological Magazine 144, 127-141.

Sancho, R., Alonso-Zarza, A.M., Calvo, J.P., 2002. El Terciario continental del sector Alfambra-Villalba Alta (Fosa de Teruel). Teruel 88-89, 37-74.

Simón, J.L., Arlegui, L.E, Lafuente, P., Liesa C.L., in press. Active extensional faults in the central-eastern Iberian Chain, Spain. Journal of Iberian Geology.

Talbot, M.T., 1990. A review of the palaeohydrological interpretation of carbon and oxygen isotopic ratios in primary lacustrine carbonates. Chemical Geology 80, 261-279.

Tandon, S.K., Andrews, J.E., 2001. Lithofacies associations and stable isotopes of palustrine and calcrete carbonates: examples from an Indian Maastrichtian regolith. Sedimentology 48, 339-355.

Tanner, L.H., 2000. Palustrine-lacustrine and alluvial facies of the (Norian) Owl Rock Formation (Chinle Group), Four Corners Region, Southwestern U.S.A: Implications for late Triassic paleoclimate. Journal of Sedimentary Research 70, 1280-1290.

Tanner, L.H., 2010. Continental carbonates as indicators of paleoclimate. In: Alonso Zarza, A.M., Tanner, L.H. (Eds.), Carbonates in continental settings: geochemistry, diagenesis and applications. : Developments in Sedimentology, 62. Elsevier, Amsterdam, pp. $179-214$

Tullner, T., Cserny, T., 2003. New aspects of lake-level changes: Lake Balaton, Hungary. Acta Geologica Hungarica 46, 215-238.

Utrilla, R, Vázquez, A., Anadón, P., 1998. Paleohydrology of the Upper Miocene Bicorp Lake (eastern Spain) as inferred from stable isotopic data from inorganic carbonates. Sedimentary Geology 121, 191-206.

Valero Garcés, B.L., Gierlowski-Kordesch, E., Bragonier, W.A., 1997. Pennsylvanian continental cyclothem development: no evidence of direct climatic control in the Upper Freeport Formation (Allegheny Group) of Pennsylvannia (northern Appalachian Basin). Sedimentary Geology 109, 305-319.

Van Dam, J.A., 1997. The small mammals from the Upper Miocene of the Teruel-Alfambra region (Spain): paleobiology and paleoclimatic reconstructions. Geologica Ultraiectina, Utrecht, 156. 204 pp.

Van Dam, J.A., Weltje, G.J., 1999. Reconstruction of the Late Miocene climate of Spain using rodent palaeocommunity successions: an application of end-member modelling. Palaeogeography, Palaeoclimatology, Palaeoecology 151, 267-305.

Van Dam, J.A., Alcalá, L., Alonso-Zarza, A.M., Calvo, J.P., Garcés, M., Krijgsman, W., 2001. High-resolution late Miocene mammal biochronology and paleoecology of the Teruel-Alfambra region (NE Spain). Joumal of Vertebrate Paleontology 21, 367-385.

Verrecchia, E.P., 2007. Lacustrine and palustrine geochemical sediments. In: Nash, D.J., McLaren, S.J. (Eds.), Geochemical Sediments and Landscapes. Blackwell Publishing, Oxford, pp. 298-329.

Verrecchia, E.P., Verrecchia, K.E., 1994. Needle-fiber calcite: a critical review and a proposed classification. Journal of Sedimentary Research A64, 650-664.

Verrecchia, E.P., Freytet, P., Verrecchia, K.E., Dumont, J.L., 1995. Spherulites in calcrete laminar crusts: biogenic $\mathrm{CaCO}_{3}$ precipitation as a major contributor to crust formation. Journal of Sedimentary Research A65, 690-700.

Vogt, T, 1984. Crôites calcaires: types et genèse. Dissertation Thèse, Univ. Louis Pasteur, Strasbourg, $239 \mathrm{pp}$.

Wells, N.A., 1983. Carbonate deposition, physical limnology and environmentally controlled chert formation in Paleocene-Eocene Lake Flagstaff, Central Utah. Sedimentary Geology 35, 263-296.

Wright, V.P., 1983. A renzina from the Lower Carboniferous of South Wales. Sedimentology 30, 159-179.

Wright, V.P., 1986. The role of fungal biomineralization in the formation of early Carboniferous soil fabrics. Sedimentology 33, 831-838.

Wright, V.P., 1990. Syngenetic formation of grainstones and pisolites from fenestral carbonates in peritidal settings: discussion. Journal of Sedimentary Petrology 60 , 309-310.

Wright, V.P., Platt, N.H., 1995. Seasonal wetland carbonate sequences and dynamic catenas: a reappraisal. Sedimentary Geology $99,65-71$

Wright, V.P., Platt, N.H., Wimbledon, W., 1988. Biogenic laminar calcretes: evidence of calcified root mat horizons in palaeosols. Sedimentology 35, 603-620.

Wright, V.P., Platt, N.H., Marriot, S.B., Beck, V.H., 1995. A classification of rhizogenic (rootformed) calcretes, with examples from the Upper Jurassic-Lower Carboniferous of Spain and Upper Cretaceous of southern France. Sedimentary Geology 100, 143-158.

Wright, V.P., Beck, V.H., Sanz-Montero, M.E., 1996. Spherulites in calcrete laminar crusts: biogenic $\mathrm{CaCO}_{3}$ precipitation as a major contributor to crust formation. Discussion. Journal of Sedimentary Research 66, 1040-1041. 